\section{gentrafaress}

Revista do Programa de Pós-Graduação em Geografia e do Departamento de Geografia da UFES

Janeiro-Junho, 2019

ISSN 2175-3709
Roswhita Scholz ${ }^{1}$

Escritora e editora da revista Exit! info@horlemann-verlag.de

Tradução de Boaventura Antunes ${ }^{2}$ Coletivo Obeco

Lisboa

boantunes@gmail.com

Revisão para o português do Brasil Ana Carolina G. Leite (PPGG/UFES)

carolinavecchia@gmail.com

Daniel M. Giavarotti

(PPGH/USP)

manzione79@gmail.com

As notas deste artigo poderão ser encontradas a partir da página 159 .

\title{
CRISTÓVÃO COLOMBO FOREVER? - PARA A CRÍTICA DAS ATUAIS TEORIAS DA COLONIZAÇÃO NO CONTEXTO DO "COLAPSO DA MODERNIZAÇÃO"
}

Introdução: colonização uma explicação corrente para a crise atual ${ }^{3}$

$\mathrm{Na}$ sequência do crash de 2007/2008, assim como de uma nova consciência da crise ecológica, tornou-se claro que o capitalismo se encontra numa "crise múltipla". Por vezes a dimensão "de gênero" é aventada como parte desta crise (cf. Demirovic et al., 2011). Neste contexto, uma referência mais acentuada às teorias da colonização assumiu uma posição importante nos discursos sobre a crise na primeira metade da década de 2010. Considerando que tais posições, até onde conheço, também parecem de algum modo óbvias para muitos que orbitam em torno da crítica do valor-dissociação, se faz necessário aqui submetê-las a uma crítica. Tais teorias têm claramente uma evidência muito imediata. Afinal, não seria verdade que hoje todos e cada um se sentem um pouco, para não dizer maciçamente, "colonizados", impelidos a render, mercantilizados, apoderados pelo capitalismo? Ademais, tais não corresponderiam igualmente às atuais teorias da crise apresentadas pela crítica do valor? Pois o capitalismo não se realiza efetivamente assim no mundo contemporâneo? Não é evidente que o mundo se tornou uma mercadoria há muito tempo e que também "nos é" expropriada "terra" de maneira intolerável?

A despeito das semelhanças é preciso aqui evidenciar e apresentar as diferenças entre as teorias da colonização e a crítica do valor-dissociação. Salientar que as teorias da colonização permanecem numa época histórica passada, não obstante tomarem a colonização de forma anacrônica como modelo transhistórico de interpretação de novos desdobramentos. Faço isso procedendo a comparações entre citações de tamanho extenso. Assim poderá se confirmar que o teorema da colonização por si só é desajeitado quando se trata da mobilidade temporal do processo de socialização capitalista; até a "mobilidade" temporal do processo capitalista tem de ser aqui cautelosamente apropriada através desta metáfora, mesmo num sentido não espacial, mas como "consequência das colonizações" (cf. Klaus Dörre, ver abaixo). Nesse sentido, voltaremos ao conceito de "acumulação primitiva” de Marx para poder entender os atuais processos de crise. Sobre o assunto são invocados/as teóricos/as, sobretudo Rosa Luxemburgo, Hannah Arendt, Burkhard Lutz e David Harvey. É o que acontece em Klaus Dörre que fez nome como teórico da coloni- 
zação na Alemanha e além. O autor resume assim o cerne das atuais ideias de colonização:

A ideia central que une as diversas variantes da teoria da colonização afirma que o capitalismo é incapaz de se reproduzir a partir de si mesmo. Para a sua manutenção as sociedades capitalistas precisam: a) de um crescimento continuado da riqueza social; b) tal crescimento só pode ser conseguido por meio da internalização de externalidades, por meio da mercantilização de terras antes não submetidas à valorização. Ao contrário do que o conceito sugere, as colonizações não se esgotam numa dimensão sócio espacial ou físico-material. A expansão do capitalismo ocorre no medium tempo, tanto fora como dentro das sociedades nacionais, tanto setorialmente como em campos específicos, e atinge diferentes modos de produção, grupos sociais, formas de vida e mesmo as estruturas da personalidade... No entanto, a racionalidade da troca de equivalentes na forma da mercadoria, que nas sociedades capitalistas tende para a generalização, nunca consegue se impor completamente, porque permanece incrustada em outras racionalidades de ação contra as quais a mercantilização reage, ou pode reagir expansivamente, continuadamente e até mesmo de forma imperialista. Entender o desenvolvimento capitalista como sequência de colonizações significa, assim, ultrapassar a construção de um capitalismo puro e ter em conta a dependência de algo externo à socialização de mercado capitalista (Dörre, 2013, p. 113 - grifos do autor).

Em seguida gostaria de discutir, no contexto da crítica do valor-dissociação, duas concepções de colonização que se destacam não apenas ao espaço de língua alemã: a teoria da colonização de Klaus Dörre, que a meu ver apresenta uma perspectiva transformada do movimento operário, e a concepção de Silvia Federici, que argumenta a partir de um ponto de vista operaísta-feminista. Em termos da lógica de exposição, será relevante apresentar neste texto a conexão entre "contradição em processo" e decadência do capitalismo, para posteriormente entrar na sua dinâmica em termos de conteúdo, na perspectiva da crítica do valor-dissociação. Neste contexto também falarei repetidamente da inaptidão da metáfora da colonização, ou de termos semelhantes, como por exemplo cerca global, como conceitos teóricos. Por fim pretendo mostrar que, sem embargo, tudo isto deve ser colocado no contexto da crítica do valor-dissociação (mais-valia), no seu caráter fragmentário, que também dá sequência a outras críticas ao racismo, anti-semitismo, anticiganismo, homofobia e disparidades sociais em suas qualidades particulares. No decurso da minha argumentação, sobretudo próximo do fim, serão ainda referidas dimensões até então não abordadas, como por exemplo processos de asselvajamento no contexto das tendências de desestatização na periferia e das intervenções políticas de ordenamento mundial crescentemente desajeitadas. O último ponto das minhas observações visa as estratégias de ação presentes nas concepções de colonização compartilhadas por Dörre e Federici.

\section{Robert Kurz: contradição em processo e decadência do capitalismo}

\section{Pressupostos básicos}

Ao contrário das diversas teorias da colonização, Robert Kurz relaciona a formação do capitalismo a múltiplos fatores, entre os quais o protestantismo. Ele destaca ainda, particularmente, o papel da "revolução das armas de fogo" no deslocamento da criação de dinheiro

\section{gengrafaress}

Revista do Programa de Pós-Graduação em Geografia e do Departamento de Geografia da UFES

Janeiro-Junho, 2019

ISSN 2175-3709 


\section{GenGrafaress}

Revista do Programa de Pós-Graduação em Geografia e do Departamento de Geografia da UFES

Janeiro-Junho, 2019

ISSN 2175-3709 para uma posição totalmente central no Absolutismo ${ }^{4}$. Sugere, assim, que o "dinheiro" fora marginal e não um constituinte social das sociedades anteriores e que o mercado, o dinheiro, o trabalho, a circulação ou a produção simples de mercadorias não podem ser tomados como constantes antropológicas. Logo, seria necessário constatar, inversamente, que na "nova maquinaria de destruição" reside "uma abstração das necessidades materiais e sociais" (Kurz, 2014, p. 117). E que a paradoxal "abstracção real" da forma do valor e o caráter transcendental da relação social a ela associada têm aí sua origem. $\mathrm{O}$ dinheiro transmutado dos primórdios da Modernidade foi a forma primordial desta abstracção real transcendental, ou seja, a mercadoria primordial que impôs a todos os objetos (...) a forma da mercadoria autonomizada, até aí inexistente (Kurz, 2014, p. 117)

Nessa situação, também a força de trabalho dos produtores e produtoras teve de ser transformada numa mercadoria; o trabalho material abstrato como princípio de socialização, tal como o dinheiro, apenas se generalizou neste momento.

Desde o século XVII, os locais de fabrico estatais para o novo fim-em-si da multiplicação do dinheiro transformaram-se em (ou surgiram a par de) «empresas privadas» manufactureiras ou proto-industriais que seguiam a mesma lógica [...]. A máquina do dinheiro foi-se desdobrando sucessivamente numa multidão de empresas de produção capitalista com o móbil do lucro, determinante também em termos subjectivos, por um lado, e com o Estado fiscal a desnatar esse processo global da produção de lucro, por outro lado - estando ambas as partes sob o ditame autonomizado de uma multiplicação interminável da «riqueza abstracta» na forma do dinheiro (Kurz 2014, p.

Aqui é preciso subdividir o conceito histórico de crise, diferenciando a constituição histórica do capital das crises que ocorriam quando ele passou a se reproduzir em suas próprias bases, com o trabalho abstrato como uma "substância material abstrata" (Kurz, 2014, p. 172 e ss.). Kurz destaca, retomando Marx, o "movimento em si mesmo" do capital. Esse processo, no entanto, não teria se desenvolvido linearmente:

(...) há que reter que a constituição e o desenvolvimento histórico do capital, durante muito tempo e até ao século XX, teve por consequência umasituação híbrida entre a lógica pura do fetiche do capital como «movimento em si mesmo», por um lado, e uma multiplicidade de modos de imposição, assincronias e mutações na estrutura do mercado mundial, por outro (Kurz, 2014, p. 217/218).

Ainda assim, para Kurz, o ponto essencial a ser considerado pela teoria da crise é a "contradição em processo", quando o capital assume seu "movimento em si mesmo". Ele escreve com referência a Marx:

Com isto (...) fica estabelecida uma contradição fundamental objectiva no seio do «sujeito automático» do fetiche do capital e da sua dinâmica histórica: por um lado, o fim-em-si da «riqueza abstracta» assenta única e exclusivamente no dispêndio cada vez maior de energia de trabalho humana, que, de acordo com Marx, é a «substância do capital», da qual o dinheiro (capitalista) não é mais que a forma de manifestação palpavelmente reificada. Por outro lado, o aumento constante das forças produtivas torna precisamente esta substância cada vez mais supérflua, retira-a do processo produtivo e acarreta assim a desvalorização lenta e, por fim, dramática das «objectualidades do valor» cada vez mais formais (paulatinamente dessubstanciadas) da mercadoria e do dinheiro. No fragmento das máquinas dos Grundrisse, Marx diz a este propósito que « (...) o capital reduz aqui a um mínimo - de forma perfeitamente involuntária - o trabalho humano, o dispêndio de energia», ou seja, precisamente essa substância da energia humana abstracta de «nervo, músculo e cérebro» (...). À energia humana constituinte de substância substitui-se, de acordo com Marx, o «poder dos agentes» que «são postos em movimento» por ela própria enquanto dimensão voltada ao desaparecimento. Deste modo, «o (...) próprio capital é a contradição em processo devido ao facto de tentar reduzir o tempo de trabalho a um mínimo, ao passo que, por outro lado, estabelece o tempo de trabalho como único critério e fonte da riqueza». No entanto, uma contradição dinâmica não pode ficar «em processo» para todo o sempre, antes tem de culmi- 
nar ou passar pelo seu clímax: «O capital trabalha assim na sua própria dissolução como forma que domina a produção». Deste modo, o fim-em-si fetichista desmente-se em si próprio e esbarra com o seu limite interno objectivo, que acaba por se tornar absoluto ou, como diz o célebre enunciado de Marx no fragmento das máquinas: «Deste modo colapsa a produção que assenta sobre o valor de troca» (Kurz, 2014, p. 234/235).

Porém, isto não acontece linearmente, mas sim mediado por passos de desenvolvimento histórico:

No entanto, o que é decisivo para um entendimento suficiente é essa outra modulação histórica que ocorre no próprio plano categorial, a saber, o mecanismo de compensação relativa, que se estende ao longo de várias épocas, devido ao qual a contradição fundamental começa por não se manifestar de imediato, não sendo tão-pouco resolvida (...), antes é reproduzida numa escala cada vez maior, e só nesse sentido é (periodicamente) ultrapassada de forma temporária (Kurz, 2014, p. 247).

Numa fase anterior do capitalismo se tratou da expansão absoluta do dispêndio de energia laboral. Posteriormente, tratou-se da elevação da parte relativa da mais-valia, por meio da aplicação de maquinaria exigida pela concorrência entre os capitais individuais. No longo prazo, contudo, este processo faz ir pelos ares o próprio automovimento fetichista. Trata-se aqui não de um "regresso do mesmo", em que o capitalismo possa continuar por toda a eternidade, mas por assim dizer de um "movimento direccionado", que se dirige para um fim.

Em termos históricos concretos é preciso levar em conta as dinâmicas de expansão interna e externa:

Mesmo quando o capital já se reproduzia «com base nos seus próprios fundamentos» (Marx) ou como «movimento em si mesmo», estava ainda muito longe de conquistar, até nos países definidos como capitalistas, a totalidade do espaço de reprodução. Estruturas definidas, do ponto de vista económico moderno, como sendo "de subsistência", assim como relações de mercadorias e dinheiro ainda associadas a resquícios das relações de obrigação (pessoais e institucionais) ainda não completamente «economificadas» [...] mantinham-se a par da relação do capital — ou com ela entrosadas - , que avançava com agressividade, se bem que em graus extremamente variáveis (Kurz, 2014, p. 258).

Aqui,

as restantes condições não se mantinham constantes; a massa pura e dura do dispêndio de capital monetário adicional aumentava de forma incessante, à medida que o capital desbravava terreno em todos os ramos produtivos e «capitalizava» o espaço terrestre neste sentido histórico, ou seja, transformava-o num espaço global da valorização. Embora o dispêndio de energia de trabalho por mercadoria diminuísse incessantemente, o número de efectivos da força de trabalho aplicados de uma forma produtiva na perspectiva do capital crescia, ainda assim, de forma contínua, devido a este movimento expansivo exterior. Através apenas de tal expansão permanente, o aumento da mais-valia relativa por elemento da força de trabalho também impulsionava adicionalmente a produção de mais-valia no que diz respeito à sua massa absoluta, que parecia crescer «até alcançar dimensões monstruosas» (...). O conceito de uma expansão «exterior» refere-se aqui à reprodução (ainda) não abarcada pelo capital (e que nunca poderá ser abarcada de forma absoluta) (Kurz, 2014, p. 258/259).

Em termos de teoria da crise, entretanto, o decisivo para Kurz é a "expansão interna do capital" que se processa nas suas próprias bases:

Na medida em que o capital incorpora em si os ramos produtivos pré-existentes e os modela à sua imagem, ou seja, transforma-os em componentes de uma produção de «riqueza abstracta», essas produções também são profundamente transformadas no seu plano interno. É esse o processo que Marx designou como transição histórica da subsunção «formal» para a subsunção «real» da actividade produtiva sob o capital. No seu decurso, as técnicas, disposições dos meios de produção, organizações de processos, etc., são adaptadas, ou seja, alienadas da sua finalidade ligada à satisfação de necessidades no sentido da produção de bens de uso (Kurz, 2014, p. 261).

Isto significa concretamente que:

A inovação dos processos refere-se a ramos produtivos já existentes ou transformados pelo capital. Na medida em que são submetidos à «subsunção real», ou seja, as suas técnicas tradicionais pré-existentes são substituídas por técnicas capitalistas, também o seu procedimento de fabrico é afetado pelas inovações permanentes; e não só a técnica propria-

\section{gengrafaress}

Revista do Programa de Pós-Graduação em Geografia e do Departamento de Geografia da UFES

Janeiro-Junho, 2019

ISSN 2175-3709 


\section{gengrafaress}

Revista do Programa de Pós-Graduação em Geografia e do Departamento de Geografia da UFES

Janeiro-Junho, 2019 ISSN 2175-3709 mente dita, como também os processos de organização ou comunicação. Se, nas industrializações de base do século XIX, a ênfase incidia ainda no aumento do recurso às máquinas mecânicas, no século XX, a partir da segunda revolução industrial («taylorismo», «fordismo»), a inovação deslocou-se crescentemente para o afinamento dos processos produtivos; não só pela famosa linha de montagem e pelas técnicas de organização do trabalho, que começaram a transformar os seres humanos em robôs, mas também com recurso a máquinas-ferramentas e logo, também, a técnicas de comando, etc. Esta chamada "racionalização" causou um surto de produtividade monstruoso (Kurz, 2014, p. 262).

Este mecanismo compensatório da "expansão interna" do capital consiste, portanto, na "poupança maciça de dispêndio de trabalho ou de energia do trabalho humano por produto". Isto

também atingia ramos produtivos que, até então, tinham estado organizados na sua estrutura interna de um modo essencialmente artesanal, mesmo que já fossem objeto de uma concentração semelhante à de uma fábrica (Kurz, 2014, p. 262).

$\mathrm{O}$ que se mostrou claramente na produção em massa de automóveis, frigoríficos e outras coisas.

\section{Globalização}

Desde a década de 1980 ocorreu um salto qualitativo no desenvolvimento das forças produtivas, na sequência da revolução microeletrônica, diante do qual o esgotamento da expansão interna da acumulação começou a se tornar claro. Isto podia ser visto, por exemplo, no fato dos computadores pessoais baratearem mais rapidamente do que os bens de consumo anteriores. "Mas faltou um momento decisivo: a saber, a expansão correspondente na aplicação adicional de força de trabalho que fosse produtiva na perspectiva do capital"
(Kurz, 2014, p. 266). O significado de tais desenvolvimentos em termos de crise se tornou evidente nas últimas décadas e particularmente no crash de 2007/2008:

Uma vez que o nexo interno é realizado por detrás das costas dos actores e não pode ser adequadamente compreendido pelas estatísticas burguesas, visto que estas se limitam a elaborar «projecções» de momentos isolados e sem nexo na percepção distorcida pelas trocas de mercadorias e dinheiro determinadas pela concorrência, a crise manifesta irrompe necessariamente de forma surpreendente e repentina, e não pode de modo algum ser explicada a partir da tacanha perspec-

tiva empírica (Kurz, 2014, p. 267).

Aqui já não pode ser gerado mais nenhum "novo modelo de acumulação"; mas a esperança em um novo regime de acumulação pode ser encontrada em algumas esquerdas.

$\mathrm{O}$ esgotamento de mercados internos importantes, os crescentes fluxos de exportação unilaterais e o seu financiamento por déficis ou bolhas financeiras [...] não constituem um deslocamento sustentável da acumulação, mas já são em si manifestações de crise extremas. Por isso, de resto, a suposta ascensão da China também não é uma continuação da expansão, quer exterior, quer interna do capital [... visto que esse «milagre» é sustentado sobretudo por déficis internos e externos (Kurz, 2014, p. 273).

Também o "novo modelo de acumulação" esperado por muitas esquerdas com relação à "sociedade dos serviços" não apareceu, pelo contrário, houve um regresso da "mais-valia absoluta":

As desavergonhadas medidas coercitivas a nível empresarial que, no plano social, parecem apontar para um regresso à preponderância da mais-valia absoluta, podem ser interpretadas como reacções cegas e desesperadas ao limite interno da produção de mais-valia enquanto tal (Kurz, 2014, p. 275).

Isto, no entanto, é apenas um estágio intermediário na decadência do capitalismo devido às revoluções tecnológicas que tornam o trabalho abstrato supérfluo - com consequências brutais e bárbaras. 


\section{Resumindo:}

O capitalismo atinge o seu clímax quando a expansão interna é atingida e ultrapassada pelo desenvolvimento das forças produtivas. Então a queda relativa da taxa de lucro se transforma numa queda absoluta da massa de mais-valia e, portanto, de lucro, esbarrando assim a supostamente eterna valorização do valor na sua desvalorização histórica ${ }^{6}$. Alguns indícios apontam que o desenvolvimento capitalista ingressou neste estado desde a década de 1980, a partir da revolução microeletrônica. O ápice da contradição interna é modificado e mediado pela expansão histórica do sistema de crédito que prossegue refletindo de modo especular a estagnação e o declínio da massa de trabalho produtora de valor. $\mathrm{O}$ permanente aumento relativo do capital real elevou progressivamente os custos mortos antecipados de maneira extraordinária, de forma que tais só poderiam ser parcialmente financiados pelos lucros correntes. O crédito transformou-se de elemento propulsor coadjuvante da produção de mais-valia no seu substituto. A acumulação alimenta-se desde então cada vez menos da substância de trabalho real pretérito e cada vez mais da antecipação de trabalho imaginário futuro. Investimentos e empregos sem qualquer base real são financiados por uma dívida global sem precedentes e pelas bolhas financeiras daí resultantes. [...]. Todavia, apesar das aparências temporárias, nestes processos não se acumula capital, como se viu na indústria da construção de muitos países após o estouro das bolhas imobiliárias [...]. Após um encadeamento cerrado de crises financeiras, que nos últimos trinta anos abalaram países e setores econômicos isolados, o crash financeiro de 2008 assumiu pela primeira vez uma dimensão global. O rompimento das cadeias de crédito coloca na ordem do dia o grande surto de desvalorização. Foram os Estados, por si só altamente endividados, que impediram o início da avalanche, por meio de injeção maciça de crédito adicional e emissão monetária [...]. As dívidas estatais impagáveis somam-se aos créditos incobráveis dos mercados financeiros, aproximando-se a fusão nuclear do sistema de crédito. $\mathrm{O}$ futuro capitalista já consumido tornou-se presente. A Grécia mostra exemplarmente que as pessoas teriam de deixar de viver durante anos para continuarem a satisfazer os critérios capitalistas. Tão logo a emissão monetária deixe de se limitar a adiar a desvalorização dos títulos da dívida, mas passe a alimentar diretamente a conjuntura econômica com dinheiro sem substância por meio da simulação de crédito, o próprio dinheiro (como forma de mediação social) se desvalorizará (Kurz, 2013, p. 235 e ss.).

Kurz tem, portanto, perfeitamente em conta processos de "colonizações" capitalistas, sem usar explicitamente este conceito. Quando utiliza algo semelhante o faz a partir de conceitos baseados em Marx, como expansão interna e externa, entre outros. O ponto crucial da sua argumentação, no entanto, é a lógica do capital compreendida como contradição em processo que aponta para seu fim, diante do que "novas colonizações", entendidas como fontes de um novo modelo de acumulação, nolens volens hão de sucumbir; novas "colonizações", "novas cercas" e a correspondente exploração como fenômenos, de maneira nenhuma serão aqui dispensados, mas tematizados categorialmente em sua dimensão histórica, tendo como pano de fundo a contradição em processo do capital.

\section{Klaus Dörre: A nova colo- nização}

\section{Pressupostos básicos}

Dörre toma a "Landnahme" como foco da sua elaboração teórica:

Landnahme significa, assim, expansão do modo de produção capitalista para dentro e para fora. Nesse sentido, a separação de grande parte da população agrícola de suas terras criou um "mercado interno": a população sem terra foi coagida a se sustentar a partir da venda da sua força de trabalho. A pura orientação às necessidades foi eliminada; matérias primas e mantimentos tornam-se mercadorias. A subsequente eliminação das indústrias auxiliares e do processo de cisão entre manufatura e agricultura causou uma reestruturação ainda mais radical, que forneceu o potencial necessário de força de trabalho para o modo de produção capita-

lista em expansão (Dörre, 2015, p. 554).

Isto se aplicou até o capitalismo começar a se reproduzir em suas próprias bases. Aí de-

\section{Gengrafaress}

Revista do Programa de Pós-Graduação em Geografia e do Departamento de Geografia da UFES

Janeiro-Junho, 2019 ISSN 2175-3709 


\section{GenGrafaress}

Revista do Programa de Pós-Graduação em Geografia e do Departamento de Geografia da UFES

Janeiro-Junho, 2019 ISSN 2175-3709 sempenhariam um papel importante as intervenções estatais, como por exemplo leis tendo por objeto a obrigação de trabalhar e a regulação do salário:

Mesmo em seus primórdios, o capitalismo nunca foi uma economia de mercado auto-regulável. O Estado atuou continuamente como parteiro indispensável para o nascimento do novo modo de produção. Ele garantiu que a formação do mercado se realizasse sob as condições de assimetrias estruturais de poder. A expansão externa do modo de produção capitalista baseou-se no fato de que o capitalismo, desde seu nascimento até a constituição de um sistema internacional interconectado acima e além dos Estado-Nações, foi impulsionado politicamente (Dörre, 2015, p. 555).

Dörre, portanto, diferentemente de Kurz, não põe em destaque a revolução das armas de fogo e a atividade estatal associada a isso durante $\mathrm{o} a b$ solutismo, como momento essencial de um contexto formal capitalista em constituição, que trazia consigo a formação do "trabalhador assalariado duplamente livre". Ele também vê, de fato, como Kurz e Marx, a libertação deste "trabalhador assalariado duplamente livre" e a valorização de matérias primas e alimentos; no entanto, para ele, o Estado tem sempre um papel central na história do capitalismo e suas "colonizações" e justamente na medida em que "conseguiu contornar as leis econômicas", como fez no fordismo (ver abaixo). Acrescente-se que para Dörre, na sua interpretação de Marx, as "assimetrias de poder" desempenham um grande papel, ou seja, a oposição das classes, enquanto para Kurz é decisivo o Marx do fetiche e do "sujeito automático". Se, para Kurz, o Estado é a instância central de ordenamento das relações fetichistas, para Dörre o Estado é mera instância judicial que também consegue se responsabilizar pela "justiça social", como comprova a história.

Sobre o papel do Estado que, justamente em função disso, tem até hoje uma grande importância para muitas esquerdas, escreve Kurz:

A transformação das estruturas feudais descentralizadas em aparelhos estatais burocráticos angariadores de dinheiro fez da estatalidade - ela própria constituída neste processo - o demiurgo dessa «reinvenção» do dinheiro. A correlação original das recíprocas produção do Estado e transmutação do dinheiro conduziu, com a sua orientação ideológica unilateral para a função de demiurgo do Estado, a uma ilusão sobre este cujos efeitos ainda hoje se fazem sentir (em especial na esquerda de todas as socialdemocracias). No entanto, esta primeira instância da «economia política» cedo perdeu o controlo sobre a sua criatura, supostamente funcional de acordo com um fim determinado. A monetarização de todas as contribuições em géneros e a contínua invenção de novos impostos, pagáveis em dinheiro, obrigaram a uma monetarização cada vez mais abrangente da totalidade da reprodução, com consequências insuspeitadas (Kurz, 2014, p. 115).

Kurz define o caráter do Estado remetendo para Marx da seguinte maneira:

É verdade que o Estado é a «forma» do «resumo da sociedade burguesa» $[\ldots]$, ou seja, da relação de fetiche capitalista e, assim, parte integrante da mesma. Precisamente por isso, porém, não pode transcendê-la no seu conceito; o que ele «resume», afinal, é justamente o processo cego da concorrência, a cujos resultados apenas pode reagir (Kurz, 2014, p. 237 e ss.).

Para Kurz, portanto, o Estado é tudo menos a possibilidade de contornar as leis econômicas, como o é para Dörre. Pelo contrário, é parte integrante imanente, moderadora e fetichista da socialização capitalista, até no processo crescente em que essa última se torna obsoleta.

Dörre critica ainda o seguinte nas posições de Rosa Luxemburgo e Hannah Arendt:

Certamente, as Landnahmen capitalistas são em diversos sentidos irreversíveis. Pense-se, por exemplo, quando absorvem modos tradicionais de produção ou 
exaurem recursos naturais. Nesse sentido, a capitalização total de mercados externos aparece como um processo no qual se deve chegar ao final a um distante ponto de fuga, pois sem mercados externos não há capitalismo (Dörre, 2015, p. 558).

Em vez disso, Dörre pretende dar a entender que as colonizações capitalistas na verdade são ilimitadas, ou que o capitalismo cria para si um exterior incessantemente, seja na forma de regiões devastadas ou também na forma de força de trabalho inexplorada. Este "exterior" poderia "em uma fase de desenvolvimento posterior [...] se tornar objeto de investimentos de reparação de longo prazo" (Dörre, 2015, p. 561).

No que se refere ao papel do Estado nas colonizações, Dörre igualmente se diferencia de David Harvey: o modus operan$d i$ delas "se baseia em formas extremamente diferenciadas de intervenção estatal" (Dörre, 2015, p. 561). Diz Dörre que

a "implosão" de leis de natureza exclusivamente econômica, como, por exemplo, a ampliação de serviços públicos, a produção de bens coletivos ou a expansão de sistemas coletivos de proteção social, pode ocorrer por meio da descomodificação (desacoplamento dos riscos de mercado) e dos compromissos de capital a longo prazo nos ciclos secundário ou terciário. Cada uma das estratégias, que Harvey descreve como "acumulação por espoliação", utiliza a privatização de instituições públicas e a desregulação dos mercados de trabalho como alavanca para uma re ou descomodificação da força de trabalho. Aplicado à problemática do desenvolvimento, isso significa que o capitalismo não pode existir sem a Landnahme, sem a utilização de ativos externos (inclusive força de trabalho ociosa) (Dörre, 2015, p. 561).

Aqui são mobilizados por Dörre níveis históricos inigualáveis, uns contra os outros. A anulação pós-moderna de domínios e mecanismos capitalistas socializados preteritamente é equiparada sem uma distinção mais cuidadosa ao mecanismo da colonização, supostamente essencial para o capitalismo. E justamente quando não se consegue sustentar um entendimento ontológico do Estado no capitalismo, como se pode ver hoje. Segundo Dörre, o que se passa fundamentalmente é o seguinte:

Em conjunturas atraentes, o exército industrial de reserva foi utilizado em suas diferentes manifestações para mobilizar força de trabalho adicional. Em tempos de crise, os excluídos da produção capitalista representam um potencial de pressão, que é empregado para manter os custos do trabalho os mais baixos possíveis (Dörre, 2015, p. 562).

Consequentemente, em Dörre "a formação deste capitalismo social-burocrático" baseia-se em

um ciclo de investimentos infraestruturais com efeitos a longo prazo; a absorção do potencial de mão de obra de um setor econômico tradicional, agrário e organizado em pequenas empresas; e a antes desconhecida institucionalização do "poder trabalhista". Sua gênese está relacionada primariamente às estratégias de descomoditização da força de trabalho (Dörre, 2015, p. 564).

No entanto, a dinâmica interna-externa da questão social também não teria desaparecido por completo na fase fordista. Ela "continuou presente através da funcionalização das atividades reprodutivas da mulher, da exploração de migrantes ou da exclusão social de uma minoria pela maioria" (Dörre, 2015, p. 567). As hipóteses relativas à colonização são, assim, transportadas para as mulheres, migrantes e outros "outsiders" de modo forçado, até um pouco relutante, sendo que se pretende que a oposição de classes continue a ser sempre o fator verdadeiramente decisivo. Ademais, a oposição das classes também continua a ser um ponto de referência central para Harvey, que funciona como o decano (mas-

\section{gengrafaress}

Revista do Programa de Pós-Graduação em Geografia e do Departamento de Geografia da UFES

Janeiro-Junho, 2019

ISSN 2175-3709 


\section{Gentrafaress}

Revista do Programa de Pós-Graduação em Geografia e do Departamento de Geografia da UFES

Janeiro-Junho, 2019 ISSN 2175-3709 culino) do teorema da colonização nos tempos mais recentes, quando as pioneiras nas novas abordagens da colonização nas últimas décadas na esquerda foram de fato feministas (cf. Feministiche Autorinnengruppe, 2013; mais sobre o assunto abaixo).

\section{Globalização}

De acordo com Dörre (2015) desde o fim da década de setenta, surgiu um novo desenvolvimento:

Ao invés de expandir a capacidade de produção e a massa da mais-valia, o objetivo primordial de uma empresa passou a ser o aumento do lucro. Não obstante o excesso de capacidade e a pressão sobre as taxas de lucro não foram os únicos focos de crise. Nas empresas, os recursos produtivos da racionalização dominante haviam se esgotado, já que a decomposição, a padronização e o controle burocrático do trabalho contradiziam crescentemente as necessidades de uma mão de obra cada vez mais qualificada. A individualização de estilos de vida e desejos de consumo se chocou com um sistema de produção em massa. No âmbito internacional, o colapso do sistema de câmbio fixo, as mudanças na divisão internacional do trabalho ${ }^{8}$ (causadas pela expansão internacional de grandes empresas), a industrialização de países subdesenvolvidos (financiada às custas da contração de dívidas) e as consequentes turbulências deram origem a um ambiente diferenciado, com regimes nacionais de acumulação (Dörre, 2015, p. 568).

Aqui se mistura mais uma vez o plano macro com o plano micro, agora notadamente com as necessidades dos empregados altamente qualificados; a crise também é explicada, primeiramente, com referência a uma modificação dos "regimes nacionais de acumulação", situação diante da qual não se entende o todo, o contexto capitalista global, o "movimento em si" capitalista à escala global. Dörre (2015) prefere manter-se categorialmente no balaio do movimento operário tradicional e no quadro de referência nacional, este último destruído pelo desmoronamento da taxa de câmbio internacional.

\section{Dörre constata que}

No entanto, as transformações mais importantes estão ocorrendo nas relações entre empresas, governos e mercados financeiros. Neste caso, a globalização se refere à crescente integração e penetração da tecnologia da informação em diversos segmentos do mercado financeiro. Dos anos 1990 até a crise global de 2008, os mercados financeiros foram o segmento econômico de maior crescimento. A esfera financeira era, em princípio, um mero efeito colateral da crescente internacionalização do comércio, da produção e das empresas, mas terminou por converter-se em uma entidade relativamente independente da atividade econômica

real (Dörre, 2015, p. 572).

O desacoplamento dos mercados financeiros é aqui central:

$\mathrm{O}$ excesso de liquidez nos mercados financeiros é o húmus no qual prospera a transformação do capital financeiro em capital fictício. Patrocinados pela desregulamentação dos mercados e acelerados pelas tecnologias de informação e comunicação, os riscos associados às transações financeiras são desmantelados e regidos por instrumentos financeiros abertos à negociação. Graças aos fundos de pagamento e crédito, $\mathrm{D}$ - expresso em títulos financeiros - se converte em mero objeto de especulação, utilizado com o objetivo de realizar D'. Naturalmente, nenhum valor novo adequado pode ser criado por tal operação - afinal, pode-se distribuir apenas aquilo que já foi anteriormente criado na economia real como mais-valia. A concepção fetichista de que o capital monetário poderia se reproduzir na forma de títulos financeiros e derivados, sem conexão com a economia real, é o ponto de partida para uma bolha financeira (Dörre, 2015, p. 573).

Neste contexto Dörre fala de um "regime de acumulação dominado pelas finanças" (2015, p. 575), ainda que seu ponto de partida apresente objeções à tese de um "regime dominado pelas finanças":

De fato, do ponto de vista da eficiência econômica, uma série de argumentos substanciais refuta a tese de um regime financeirizado. Em tais casos, defende-se a perspectiva inversa de que o capitalismo financeiro não advém da implementação de um modelo de produção superior ou particularmente eficiente. Diferentemen- 
te do fordismo, a hegemonia da realidade financeira não está baseada primariamente na fábrica, na combinação de conceitos de racionalização superiores ao consumo de massa. Real é aquilo efetivamente implementável em termos de poder. A nível transnacional, o novo regime delegou ao mercado financeiro funções econômicas centrais de determinação, nivelamento e direcionamento dos investimentos. Tal regime levou a transformações profundas no sistema da governança corporativa, afetou fusões e reorganizações de empresas e influenciou os níveis de consumo e o comportamento do consumidor (Dörre, 2015, p. 576 - grifos do autor).

Mesmo sendo as finanças, com suas especificidades, dominante na orientação do novo capitalismo, tem de ser sublinhado ainda assim que ele não constitui nenhum novo regime, no sentido de um "regime de acumulação"; ou seja, não constitui nenhum novo modelo que represente um novo ciclo de valorização, no sentido de uma perpetuação do capitalismo; pelo contrário, o capitalismo do mercado financeiro anuncia $o$ fim do capitalismo. Sua configuração atual justamente representa a "desubstancialização do capital" e a "desvalorização do valor" com relação ao capitalismo em sua totalidade e que, portanto, não pode ser explicado apenas a partir da natureza das modificações interempresariais.

Dörre vê aqui sobretudo três mecanismos de "transferência": "(1) Valor para acionistas e controle centrado no mercado" $(2015$, p. 576 - grifo do autor). Para os empresários a questão já não é o lucro em si, mas o "rendimento do capital próprio".

A primazia fordista da economia de produção perante a economia de mercado é invertida. A organização corporativa passa a se orientar tanto pelos mercados de consumo quanto pelos mercados financeiros e constrói estruturas organizacionais condizentes [...]. A empresa verticalmente integrada é desmembrada; o princípio da subsidiação cruzada é eliminado tanto dentro das empresas quanto nas próprias obras. Desta forma, as conjunturas de venda atingem diretamente as unidades organizacionais. $\mathrm{O}$ resultado não é uma organização uniforme, e sim uma reestruturação permanente (Dörre, 2015, p. 578).

Acrescentando, ainda, mais uma reflexão:

Embora as hierarquias e as formas burocráticas de organização não desapareçam, a gerência usa o "poder difuso" do mercado para disciplinar a força de trabalho a defender determinados interesses. Empresas e trabalhadores devem agir de acordo com o mercado, usando recursos próprios para amortecer flutuações econômicas e ameaças de crise. Uma alavanca importante para gerar uma flexibilidade compatível com o mercado é a perpetuação da concorrência entre os trabalhadores (Dörre, 2015, p. 578-579).

Como segundo mecanismo de transferência ele vê um "dispositivo regulador baseado na concorrência" (2015, p. 580). Com referência a Boltansky e

\section{Chiapello, escreve:}

Aqui já são abordadas as mudanças no dispositivo regulador, cruciais na transição para o capitalismo financeiro. O propulsor é um novo espírito do capitalismo que, condizente com a ortodoxia do mercado anteriormente descrita, proclama a primazia da socialização do mercado sobre o controle hierárquico e a rigidez burocrática. Porém, este espírito só é hegemônico porque se apresenta como projeto de libertação. A ortodoxia do mercado absorveu a mesma crítica ao capitalismo que, durante o fordismo tardio, opunha os movimentos sociais ao regime dominante (Dörre, 2015, p. 580).

Como terceiro mecanismo de transferência ele indica a "precarização":

Quando a promessa de liberdade do liberalismo de mercado se torna obsoleta, ela é complementada por um novo regime disciplinar. Por exemplo, o Hartz IV, o seguro-desemprego alemão, aumenta a disposição para fazer concessões, especialmente entre os sujeitos que ainda têm um emprego. Vistas de maneira sistemática, as regras estritas da razoabilidade no capitalismo financeiro exercem uma função similar à exercida pelas relíquias legais do período feudal no contexto da acumulação primitiva. Elas ativam e disciplinam os trabalhadores em prol de uma forma de produção nova e flexível. [...] o compromisso-base do social no fordismo é irreversivelmente rompido. Ainda na superfície de instituições aparentemente estáveis, os modelos de produção e os dispositivos sociais de regulação promoveram mudanças no regime

\section{Gengrafaress}

Revista do Programa de Pós-Graduação em Geografia e do Departamento de Geografia da UFES

Janeiro-Junho, 2019 ISSN 2175-3709 


\section{GenGrafaress}

Revista do Programa de Pós-Graduação em Geografia e do Departamento de Geografia da UFES

Janeiro-Junho, 2019 ISSN 2175-3709 de acumulação que, no geral, apontam para um novo estado físico na sociedade. (Dörre, 2015, p. 585).

Isso também significa que:

No caso de crises financeiras, o modus operandi da Landnahme tem efeitos diretos sobre as relações de propriedade. Títulos de renda são desvalorizados, voltando a circular com um novo proprietário e a preço de pechincha (Dörre, 2015, p. 586).

De acordo com Dörre, após o crash de 2008 as novas intervenções do Estado continuam a "acumulação por expropriação" (Dörre, 2015, p. 586) na forma de cortes nas aposentadorias, por exemplo. Bancos e empresas sistemicamente relevantes são amparados pelos Estados. Há aqui pressão do "management" e das correspondentes instituições no sentido de um "risco moral" (2015, p. 587). Dörre também determina como complexo causal da crise "os desequilíbrios da economia global e os limites da política monetária", bem como "a falta de transparência dos produtos financeiros" (2015, p. 588) e respectivos riscos (visíveis, por exemplo, na crise do subpri$\mathrm{me})$. Sobre este particular não posso entrar aqui em pormenores. Para Dörre a crise do mercado financeiro é simultaneamente uma crise social, em que o medo do declínio social representa uma marca essencial. Isto ainda tem por consequência que:

Quando a racionalidade do capitalismo financeiro - incluindo seus mecanismos de transferência - falha tão claramente em realizar as ambições de eficiência auto-estabelecidas, os problemas de legitimação do novo regime de mercado são evidentes [donde se deduz] que a Landnahme do capitalismo financeiro provoca limitações intrínsecas (Dörre, 2015, p. 596-598).

A esperança de Dörre é que a estrutura social contraditória também continue a criar movimentos de contestação, sendo a ecologia (alterações climáticas, etc.) um campo central do problema. "Talvez o caminho do capitalismo eco-social realmente proporcione um resgate temporário do sistema" (Dörre, 2015, p. 600). Neste particular, de acordo com Dörre, não são apenas os movimentos dos trabalhadores que são centrais, como por exemplo no Brasil e na África do Sul. Ele aposta também na

[reconstrução de] setores eliminados
pelo setor privado - como a economia
solidária ou o setor público. Se existe
uma resposta conceitual às perguntas do
trabalhador temporário, a melhor expres-
são para descrevê-la é democracia eco-
nômica. Nos últimos anos, sociólogos
analisaram as variações do capitalismo;
a democracia econômica implica buscar
um modo de superá-la (Dörre, 2015, p.
603 - grifos do autor).

Desta feita se torna claro que Dörre simplesmente declara radicais aquelas soluções estratégicas reformistas antes definidas como intrínsecas. E assim, pretende-se que seja pago tributo aos novos desenvolvimentos. Isto também se aplica às "novas" soluções da questão da transformação aparentemente distantes do movimento operário, como por exemplo aquelas relativas à "economia solidária", que para ele representam uma opção no seu quadro reformista "radical". Perante este pano de fundo, Dörre constata logo em seguida que também seria o caso de incluir outros sujeitos para além do trabalhador assalariado, como por exemplo, mulheres e migrantes (discutirei de forma mais detalhada sobre este aspecto na conclusão das minhas observações, como já afirmado anteriormente).

Dörre extrai a sua concepção de colonização recorrendo a Gramsci, além de incluir refle- 
xões provenientes da teoria da regulação e igualmente da teoria das "ondas longas" (2015, p. 559). Ao que se expõe é possível contrapor a constatação de Kurz com relação à teoria institucional, nomeadamente que

a teoria institucional é apropriada, na melhor das hipóteses, para argumentar a partir da lógica fundamental da dinâmica capitalista, o que significa esclarecer a crise apenas a partir de fenômenos sociais variados e de interações institucionais, culturais, etc. com a "economia", enquanto a lei do desenvolvimento histórico interno em si permanece uma black box (Kurz, 2005, p. 425 e ss. - grifo do autor).

E no que diz respeito à teoria da regulação também pode ser atribuído a Dörre que:

$\mathrm{O}$ que permanece totalmente velado na teoria da regulação, como em todas as anteriores teorias dos estágios ou das ondas, é a relação das respectivas configurações, modelos, regimes, ondas, estágios, etc. com a forma do valor e a sua substância, o "trabalho abstrato" [...]. É simplesmente um pressuposto a priori que sempre se voltará a produzir "taxa e massa suficiente' de mais-valia e de lucro em cada novo momento, em novas configurações, etc.. [...] A maior parte de O Capital de Marx, da análise da forma valor até a queda tendencial da taxa de lucro, é completamente supérflua para a teoria da regulação, tal como para teoremas assemelhados; os conceitos são, de fato, ocasionalmente mencionados, mas de modo nenhum mobilizados como instrumentos de análise (Kurz, 2005, p. 425).

Trata-se "sempre apenas de manifestações superficiais históricas desta estrutura fundamental ontologizada, exatamente como no marxismo tradicional" (Kurz, 2005, p. 429).

No caso de Dörre estas manifestações são depois subsumidas ao conceito fenomenológico de "Landnahme", isto é, ele vê a troca de mercadorias e de equivalentes como "aparência" e as relações de exploração e de dominação como a verdadeira essência (cf. Dörre, 2015, p. 43). É possível reconhecer neste procedimento de Dörre a adesão a um "individualismo metodológico", no sentido que lhe atribui Kurz (cf. 2014, p. 53-63) no contexto de uma crítica à teoria dos sistemas:

Os «factos» ou as «ações» individuais só são abstraídos indutivamente, em certa medida, até ao famigerado "plano meso» dos chamados domínios, ao passo que a verdadeira relação global desaparece, por assim dizer, no nevoeiro e apenas surge como ligação exterior ou como um dito efeito recíproco entre os «verdadeiros» domínios individuais (Kurz 2012, p. 154).

É verdade que em Dörre também se fala de possíveis "limites" do capitalismo, mas estes estão, de forma paradoxal, tematizados no contexto de teorias que, em sua essência, supõem a infinitude do capitalismo e, nesse sentido, não são nada apropriadas para avançar logicamente para um fim do capitalismo, como acontece com a concepção de uma contradição em processo levada até o fim.

As "Landnahmen" identificadas hoje como tais não devem ser simplesmente subsumidas a um conceito geral de colonização; pelo contrário, têm de ser colocadas no contexto complexo desta contradição em processo; pensados como "princípio" os teoremas da colonização e as hipóteses sobre as possibilidades infinitas de acumulação induzem ao erro. No caso de Dörre, mas não só, a sua intervenção funciona no sentido de uma auto-salvação do capitalismo, ao invés de sua suplantação. Eu diria que isto é, aproximadamente, o programa secreto da esquerda que, com todas as suas pretensas diferenças, não quer saber de uma "ruptura categorial" e se coloca assim, de fato, disposta para a futura administração da crise, incluindo aqui concepções vulgares da crítica do valor.

\section{gengrafaress}

Revista do Programa de Pós-Graduação em Geografia e do Departamento de Geografia da UFES

Janeiro-Junho, 2019 ISSN 2175-3709 


\section{GenGrafaress}

Revista do Programa de Pós-Graduação em Geografia e do Departamento de Geografia da UFES

Janeiro-Junho, 2019 ISSN 2175-3709
Silvia Federici: acumulação primitiva, reprodução e globalização

\section{Pressupostos básicos}

Até agora não se falou da reprodução, no sentido de uma "dissociação do feminino" no conjunto da reprodução social. Para Dörre ela consiste no trabalho feminino de reprodução, entendido como "exterior" ao capitalismo, que (no seu entendimento) nada tem a ver com aquela forma, ainda que possa, por outro lado, representar uma reserva para a apropriação capitalista, questão a que voltarei posteriormente. Para Kurz, esta dissociação é central para o conjunto da reprodução (cf. Kurz, 2005). No entanto, no seu livro Dinheiro sem valor, por exemplo, ela não é examinada de maneira sistemática (cf. Kurz, 2014). Silvia Federici, pelo contrário, promete ter efetivamente em conta este problema, referindo-se "às de Bielefeld", mas não oferece mais do que uma leitura operaísta do mesmo 9 :

A minha tese é que a teoria marxista que pretenda ter ressonância nos movimentos anticapitalistas do século XXI tem de repensar a questão da "reprodução" e dos seus diversos aspectos (como reprodução dos indivíduos e reprodução da força de trabalho) e isto numa perspectiva que tenha em conta o conjunto do planeta. Se pensarmos nas atividades por meio das quais a nossa vida é reproduzida, podemos ultrapassar a ilusão de que o desenvolvimento capitalista esteja em posição de criar as condições materiais para uma sociedade não exploradora. Podemos também evidenciar que os obstáculos no caminho da "revolução" não consistem meramente na falta ou indisponibilidade de know-how técnico, mas sim na desvalorização sistemática da vida humana e nas cisões que, além disso, o desenvolvimento capitalista produz no interior da comunidade global de trabalhadores e trabalhadoras (Federici, 2012, p. 24).
Segundo Marx,

o valor da força de trabalho também é calculado através do valor das mercadorias (alimentação, vestuário, habitação) "sem cujo fornecimento diário o portador da força de trabalho, a pessoa, não poderia renovar o seu processo vital", portanto, através do tempo de trabalho necessário à sua produção (Federici, 2012, p. 27).

Contra isso, Federici constata, em consonância com Mariarosa Dalla Costa, que o trabalho não remunerado da reprodução "produz a mercadoria mais importante para a sociedade capitalista, da qual depende a produção de todas as outras mercadorias: a força de trabalho" (Federici, 2012, p. 39 e ss.).

A concepção de Federici, a meu ver, pode ser subsumida, com razão, no conceito geral das "teorias da colonização", mesmo que ela não tome este conceito explicitamente como central. Referindo-se ao trabalho de Angelis e Lazzarato (2013, p. 40), Federici cita a seguinte passagem:

a acumulação primitiva não foi um acontecimento histórico único (...), limitado à origem do capitalismo, como ponto de partida da "acumulação como funcionamento habitual das coisas" (...). Pelo contrário, é um fenômeno que em qualquer altura está na base, que é constitutivo das relações capitalistas e se repete sempre como "parte do processo contínuo da acumulação capitalista" (...) que traz sempre consigo simultaneamente a sua expansão (Federici, 2012, p. 41).

\section{E prossegue:}

a "separação dos produtores dos seus meios de produção" (...), para Marx, a chave essencial da acumulação primitiva, tem de ser percebida como algo que se repete continuamente, particularmente em tempos de crises capitalistas, quando as relações de classe são desafiadas e precisam novamente estabelecer seus fundamentos (...). No contexto da resistência generalizada contra a regulamentação capitalista e o empobrecimento da nossa vida, não admira que a acumulação primitiva pareça ter-se tornado um processo duradouro, com crises econômicas, guerras e expropriações maciças, que agora parecem ser os pressupostos para a organização da produção e da acumulação à escala mundial (Federici, 2012, p. 41 - grifo do autor). 
Essa leitura deixa claro que, para Federici, classe, luta de classes, trabalho e acumulação primitiva são categorias permanentes no capitalismo e, portanto, vigoram também na era da globalização. O ponto de partida para Federici é aqui subjetivo-operaísta de uma ponta à outra, excluindo qualquer hipótese de uma socialização fetichista. Essa perspectiva submete a problemática de gênero. E não apenas isso, pois segundo Federici a teoria da luta de classes de Marx deveria de ser alargada:

Temos de reconhecer que a história da acumulação primitiva não pode ser entendida do ponto de vista de um sujeito abstrato universal. Um aspecto importante do projeto capitalista foi a desarticulação do corpo social, tendo as pessoas sido obrigadas a diferentes regimes disciplinares, que produziram uma acumulação de "diferenças" e hierarquias. Estas influenciam profundamente o modo como as relações capitalistas são experimentadas (Federici, 2012, p. 41).

Aquela história, portanto, teria também de ser escrita

do ponto de vista dos escravizados, dos colonizados, dos povos indígenas, cujas terras, além disso, são o objetivo principal das cercas - em síntese, de todos aqueles sujeitos cujo lugar na história do capitalismo não pode ser equiparado à história do trabalhador assalariado (Federici, 2012, p. 42).

Pretende-se, com isso, que uma multiplicação díspar e pós-moderna de sujeitos seja reinterpretada do ponto de vista do marxismo do movimento operário. Aqui se evidencia o tabu da abstração, que nas últimas décadas tem sido característico no feminismo e não só (cf. Scholz, 2011). Os contextos abrangentes são suspensos e o ponto de partida metodológico coincide imediatamente com a vivência e com as diversas preocupações, como é característico de posições operaístas. Seria possível considerar as di- ferenças qualitativas do "ponto de vista dos escravizados", sem, contudo, por isso, deixar de relacionar aqueles contextos ao contexto abrangente, embora fragmentário, da relação de dissociação-valor. Quando se hipostasia o lado subjetivo da relação, anuncia-se ainda o perigo de "sorelização", uma espécie de invocação vitalista da "existência" imediata de maneira abstrata e no sentido de uma falsa imediaticidade não dialética, existência que em si não tem qualquer conteúdo nem orientação e, portanto, pode derivar igualmente para a direita. Isso ocorreu, por exemplo, na chamada rebelião árabe - mencionada, entre outros, por Federici, elencando a dança das resistências - como se tornou amplamente conhecido.

Karin Priester fala neste contexto de uma "filosofia vitalista pós-moderna" (Priester, 2008, p. 84; Scholz, 2009, p. 83 e ss.). A (suposta) tomada em conta do ponto de vista dos colonizados [Kolonialisierten], dos escravizados ou dos "povos" indígenas pode, assim, se transformar em uma queixa chauvinista da própria colonização [Kolonialisierung] e ocupação, por exemplo, pelos EUA, ou mesmo por um capital financeiro judaico. Acresce que Federici supõe que, da situação de escravatura, proletarização, repressão das mulheres etc., segue-se nos grupos e indivíduos afetados uma experiência e consciência homogênea; mas não tem de ser de modo algum esse o caso, como indicaram justamente as análises pós-modernas e pós-estruturalistas,

\section{gengrafaress}

Revista do Programa de Pós-Graduação em Geografia e do Departamento de Geografia da UFES

Janeiro-Junho, 2019 ISSN 2175-3709 


\section{Gengrafaress}

Revista do Programa de Pós-Graduação em Geografia e do Departamento de Geografia da UFES

Janeiro-Junho, 2019 ISSN 2175-3709 mesmo se no caso se entregaram a uma hipostasiação da diferença, passando os planos estruturais objetivos para outro mundo. É preciso aqui fazer justiça plenamente aos colonizados e escravizados, mas não no sentido redutor de uma falsa imediaticidade, como acontece em Federici (ver mais abaixo).

\section{Mulheres, reprodução e glo- balização}

Para Federici a caça às bruxas desempenhou um papel importante no processo de acumulação primitiva nos séculos XVI e XVII:

Foi a caça às bruxas que possibilitou ao Estado apropriar-se dos corpos das mulheres e transformá-los em máquinas de reprodução da força de trabalho, pois foi criminalizada qualquer forma de contracepção e interrompida qualquer forma de controle reprodutivo utilizado pelas mulheres. A caça às bruxas também serviu para destruir as formas de cooperação existentes entre as mulheres pois, uma vez sob tortura, vizinhas e amigas foram obrigadas a acusar-se umas às outras e a colocar qualquer forma de associação feminina sob suspeita de bruxaria. Finalmente aprofundaram-se as divisões entre homens e mulheres, tendo o poder das mulheres sido apresentado como poder que as mulheres usariam sem mais contra os homens para destruírem os seus corpos e almas. Deste modo, a caça às bruxas nos séculos XVI e XVII desempenhou um papel chave na formatação da sociedade capitalista moderna, uma vez que as hierarquias com base no sexo e as identidades construídas foram centrais para a definição da organização capitalista do trabalho e para a disciplina laboral capitalista (Federici, 2012, p. 43). ${ }^{10}$

A caça às bruxas e o disciplinamento do corpo para Federici tem de passar pelo crivo do marxismo operaísta do movimento operário e serem considerados como pano de fundo de outras dimensões da repressão. Mistura-se aqui o processo de constituição do capitalismo com os seus atuais níveis de de- senvolvimento, assumindo-se a existência de um processo duradouro de acumulação primitiva. Para se conseguir esclarecer o disciplinamento dos corpos no capitalismo, no entanto, não é preciso tomá-los como ponto de partida absoluto, como faz Federici. Pelo contrário, a importância e o papel da caça às bruxas no início da Idade Moderna somente se tornam claros se considerados como transição na história de constituição do patriarcado capitalista, até que o capitalismo comece a se reproduzir sobre seus próprios fundamentos. Trata-se de localizar este desenvolvimento no contexto do valor-dissociação (e não apenas do valor, ou da mais-valia) como determinação fundamental do patriarcado capitalista; e neste contexto preciso é que o disciplinamento dos corpos e a caça às bruxas tiveram uma importância única. Caso contrário o corpo sofredor em abstrato desmente-se a si mesmo e torna-se mero joguete dos interesses do antigo marxismo, ou do operaísmo, no contexto de uma "falsa imediaticidade". A caça às bruxas no início da Idade Moderna também é importante para Kurz, mas sob o ponto de vista da crítica do fetichismo (Kurz, 2014, p. 120 e ss.); voltarei a isso mais abaixo); Dörre, por sua vez, é completamente omisso sobre o tema.

Através do aumento da jornada de trabalho, continua Federici, e da máxima redução de custos no século XIX, possível com a introdução das mulheres no processo de trabalho (apesar da sua menor avaliação em 
comparação com os homens), muitas atividades de reprodução ficaram desde logo prejudicadas; consequentemente a mortalidade infantil, para ficarmos num exemplo, era alta (cf. Federici 2012a, p. 28). Todavia, logo isso se modificou:

Em termos marxistas, o desenvolvimento do trabalho reprodutivo e a formação da dona de casa em tempo integral daí resultante foram consequências da passagem de um modo de exploração do trabalho assente na extração de mais-valia "absoluta" para outro assente na extração de mais-valia "relativa" (Federici, 2012, p. 30).

Em outras palavras a redução da jornada de trabalho foi compensada pela aplicação da técnica e o aumento da intensidade do trabalho. Na sequência desta transição foi investido mais trabalho e mais dinheiro na reprodução dos/as trabalhadores/as. O salário médio do trabalhador masculino subiu, também determinado pelo contexto de uma nova política salarial.

Marx não entendeu a importância do trabalho reprodutivo porque aceitava os critérios capitalistas sobre o trabalho e a prosperidade, assumindo o ponto de vista de que o desenvolvimento do trabalho industrial teria atingido um tal grau em que era iminente a luta da humanidade pela emancipação da exploração (Federici, 2012, p. 32).

Consequentemente, o aumento da atividade profissional das mulheres nas últimas décadas, segundo Federici, deve ser assim avaliado. É preciso

constatar que a entrada das mulheres no mercado de trabalho ocorreu no período de uma ofensiva histórica contra os direitos e reivindicações dos/as trabalhadores/ as, no qual as reduções de custos empresariais, a reespacialização de partes do processo produtivo e o abrandamento das determinações relativamente aos direitos trabalhistas conduziram a um rebaixamento dos salários tornando o trabalho precário e cada vez mais insalubre. Não admira que os postos de trabalho à disposição das mulheres estejam no fim da escala salarial. Trata-se das atividades mais monótonas, mais inseguras e pior remuneradas. Agora, mesmo estes postos de trabalho se encontram ameaçados, justamente pela crise econômica mundial que já incide - ainda que apenas numa dimensão limitada - numa parte das mulheres presentes no mercado de trabalho (Federici, 2012, p. 72).

As mulheres estão frequentemente empregadas em atividades do setor de serviços que outrora foram abertos à iniciativa privada. Além disso elas próprias tiveram que voltar a executar os serviços em falta, devido aos cortes nos serviços sociais. Trabalham agora designadamente nos chamados "call centers".

Nos centros capitalistas partes significativas das atividades domésticas foram retiradas de casa e comercializadas. Aumentaram as casas nas quais apenas uma pessoa mora. No entanto:

Enquanto os saltos tecnológicos nos domínios chave da economia mundial induziram uma reordenação da produção, na esfera do "trabalho doméstico" não ocorreu nenhum salto tecnológico que tivesse diminuído significativamente o tempo de trabalho socialmente necessário para a reprodução dos/as trabalhadores/as (Federici, 2012, p. 75)

E isto apesar de o computador também ter, em parte, entrado no domínio da reprodução. Assim, por exemplo, as compras e o trabalho sexual podem ser "tratados" deste modo. Para além do Twitter e do Facebook, surgem novas redes sociais. Trabalha-se com robôs de apoio pessoal entre outros (Federici, 2012, p. 75). Tudo isto, no entanto, não pode constituir nenhuma "substituição do trabalho de reprodução da vida", "pois este inclui a satisfação de necessidades complexas de tal modo que os aspectos físicos e afetivos estão indissociavelmente ligados uns aos outros e em grande medida são exigidos [...] em interação humana" (Federici, 2012, p. 75 e ss.). Estas atividades apresentam uma

\section{gengrafaress}

Revista do Programa de Pós-Graduação em Geografia e do Departamento de Geografia da UFES

Janeiro-Junho, 2019

ISSN 2175-3709 


\section{Gentrafaress}

Revista do Programa de Pós-Graduação em Geografia e do Departamento de Geografia da UFES

Janeiro-Junho, 2019 ISSN 2175-3709 estrutura temporal diferente daquela do trabalho abstrato e são amiúde assumidas por migrantes. Através da desvalorização do trabalho doméstico que continua a existir, o trabalho doméstico pago, com as suas condições miseráveis, torna-se o "pendant ${ }^{11}$ em termos de tempo histórico, do trabalho nas plantações" (Federici, 2012, p. 77). Aqui são sobretudo as mulheres do Sul que têm de enfrentar as consequências negativas da globalização. Elas hoje têm que se esforçar mais para conseguir seus meios de subsistência, devem cuidar dos doentes etc. As mulheres recorrem frequentemente ao trabalho domiciliar, com salários ínfimos, para conciliarem família e profissão. No entanto, é preciso notar aqui que as atividades femininas de reprodução têm um caráter diferente daquele trabalho nas plantações, porque estão submetidas a uma "lógica de gastar tempo" e são desenvolvidas privadamente; pelo contrário, o trabalho nas plantações, que no "Terceiro Mundo" se conformou desde a formação do capitalismo como uma espécie de pendant do trabalho fabril, ocorria na esfera pública e era marcado por uma "lógica de poupar tempo" (cf. Frigga Haug). É indispensável estabelecer aqui as diferenciações.

\section{Globalização, (re)colonização} [Re-Kolonialisierung] e reprodução

Federici entende por

globalização uma série de medidas políticas, através das quais o capital internacional reagiu à crise do trabalho e da acumulação nos anos de 1960 e 1970.
Nestes anos ocorreu um extraordinário ciclo de luta a nível mundial, estimulado pelos movimentos anticoloniais e pelo movimento dos direitos civis nos EUA. Foram mobilizados continuamente novos sujeitos (Federici, 2012, p. 50).

Ela parte aqui da questão de saber "como as mudanças sociais das últimas quatro décadas repercutiram na reprodução da força de trabalho" (Federici, 2012, p. 51). Assim, a autora vê na globalização um "processo de 'recolonização' [Rekolonialisierung]" (Federici, 2012, p. 60 e ss.) que se estendeu por todo o mundo.

Ela então assume posições que consideram a informatização e a financeirização como os aspectos principais da globalização:

Segundo uma ideia muito divulgada, a "contrarrevolução" capitalista que constitui o cerne da globalização consistiu em um duplo deslocamento. Em primeiro lugar, um tipo de acumulação assente na produção de mercadorias seria substituído por outro em que predomina a financeirização. Em segundo lugar, ter-se-ia passado da produção industrial assente na fábrica para um arranjo em que ciência, conhecimento, informação e cultura seriam os mais importantes objetos da produção, o que teria levado a uma crescente desmaterialização do trabalho e a uma menor procura de trabalho (...). Conceitos como "sociedade do conhecimento" e "revolução informática" são utilizados atravessando linhas de divisão política e a Internet é vista como modelo de novas formas de cooperação e de produção de bem-estar (Federici, 2012, p. 51 e ss.)

Em Hardt e Negri o diagnóstico é "capitalismo do conhecimento" e, em Jeremy Rifkin, "fim do trabalho". Neste contexto, Federici também critica as referências da esquerda e do feminismo ao "Fragmento das máquinas" dos Grundrisse de Marx (Federici, 2012, 52). Para ela, pelo contrário, mais importante é "a capacidade de o capital fazer baixar os custos de produção dos/as trabalhadores/ as através de um alargamento em grande escala do mercado 
de trabalho mundial" (Federici, 2012, p. 53). Ela assume aqui o aumento permanente de trabalho, justamente na era da globalização. Mesmo reconhecendo perfeitamente que ocorreu uma revolução microeletrônica, para ela o decisivo é a expansão da força de trabalho a nível mundial, o que obviamente é diametralmente oposto à hipótese de uma "contradição em processo".

O processo da globalização, prossegue Federici na perspectiva operaísta que assume,

agudizou a desigualdade e a polarização social e econômica. As hierarquias, que marcaram historicamente a divisão sexual e internacional do trabalho, e que tinham sido evitadas pelos movimentos anticoloniais e pelo movimento das mulheres, foram firmemente restabelecidas pelo mesmo. As ex-colônias têm sido até hoje o centro estratégico da acumulação primitiva [...]. As colônias foram o palco das formas de exploração mais intensivas. Foram o lugar da escravidão e da plantation. Das antigas regiões coloniais foram durante séculos retirados os mais valiosos recursos (prata, ouro, diamantes, madeira, borracha, trabalho vivo) para depois serem embarcados para a Europa e os EUA. Designo estas regiões como "centro estratégico" porque a sua reorganização econômica e social se tornou o fundamento e condição da reorganização global da produção no mercado de trabalho mundial. De fato, nunca teria sido possível a Europa e os EUA exporem-se à "desindustrialização", destruírem as estruturas organizativas em que se apoiaram as comunidades de trabalhadores/as europeias e norte-americanas e deslocarem as instalações industriais para onde os custos salariais são mais baixos se a reorganização econômica das antigas colônias não tivesse desenvolvido um grande reservatório de força de trabalho e esta força de trabalho não tivesse sido fornecida ao mercado mundial. Portanto, não por acaso foi nas colônias aonde vimos os primeiros e mais brutais processos de expropriação e empobrecimento, os mais radicais desinvestimentos públicos na reprodução da força de trabalho e os mais violentos ataques às populações locais. Tais ataques aconteceram, quer na forma de sangrentas guerras por procuração, como as desenvolvidas nos anos de 1980 e 1990 na América Central e que se podem ver até hoje em muitos países africanos, quer na forma de intervenções militares diretas, como na Somália, Afeganistão e Iraque. De fato, a violência mais uma vez tem sido a "parteira" de uma nova forma de acumulação. Através dela se abriram novos territórios à extração de petróleo, diamantes, lítio e coltan. Simultaneamente, foram recrutados novos corpos para o mercado de trabalho e os antigos senhores coloniais puderam assegurar o controle geral total da economia política. As expropriações de terras a isso associadas provocaram uma nova diáspora, empurrando milhões de pessoas do campo para as cidades, que se assemelham cada vez mais a campos de refugiados (Federici, 2012, p. 60 e ss.).

Segundo Federici, no "Terceiro Mundo" o desemprego aumenta e os salários diminuem dramaticamente. As populações foram privadas da terra que servia para a extração de matérias primas e produção de alimentos:

Centrais elétricas públicas ficaram fora de serviço [...]. Foram reduzidos os orçamentos públicos para a saúde e educação, bem como subvenções e serviços de apoio à agricultura, que deviam possibilitar a satisfação das necessidades humanas básicas. Em consequência, baixa a expectativa de vida e assiste-se ao regresso de fenômenos dos quais tinha sido assumido que a "influência civilizatória" do capitalismo os teria feito desaparecer da face da Terra: fomes, subalimentação, epidemias periódicas e até a caça às bruxas. Só na África foram mortas milhares de mulheres como supostas bruxas [...]. Isto tem sua origem, em parte, em manipulações das autoridades locais, que apontam para supostas ameaças de bruxaria a fim de desviar a atenção da liquidação do território comunitário. A caça às bruxas em parte também se explica pela depreciação a que foram votadas as mulheres idosas, que vivem de atividades de economia de subsistência em sociedades crescentemente monetarizadas (Federici, 2012, p. 63).

$\mathrm{Na}$ determinação do processo que conduz à globalização, torna-se agora perfeitamente claro que Federici não relaciona as tendências para o colapso e o desenvolvimento das forças produtivas, como Marx invoca no "Fragmento das máquinas". Para ela, o trabalho abstrato não se torna obsoleto, nem ocorre a dessubstanciação do capital e a desvalorização do valor, provocados, ambas, pela contradição em processo, segundo a formulação de Kurz. De maneira tipica-

\section{gengrafaress}

Revista do Programa de Pós-Graduação em Geografia e do Departamento de Geografia da UFES

Janeiro-Junho, 2019

ISSN 2175-3709 


\section{Gengrafaress}

Revista do Programa de Pós-Graduação em Geografia e do Departamento de Geografia da UFES

Janeiro-Junho, 2019 ISSN 2175-3709 mente operaísta, em vez disso ela vê na globalização uma "recolonização" [Re-Kolonialisierung], enquanto "contrarrevolução", no sentido de um entendimento subjetivista das classes, mesmo que modificado. Às posições que descobrem na financeirização um novo tipo de acumulação ela contrapõe uma acumulação eterna do capital. Para ela não existe qualquer "clímax do capitalismo". Ele pode de fato continuar a existir até o fim dos tempos e a mobilizar à escala mundial força de trabalho mal remunerada.

Segundo Federici, acontece mesmo uma expansão do trabalho, uma vez que também as atividades femininas de reprodução, as atividades de subsistência dos camponeses, as atividades na economia paralela, entre outras, se apresentam como "trabalho" e, portanto, supostamente criam "valor". As atividades femininas de reprodução são para ela particularmente relevantes dado que a elas cabe o papel de reprodução da força de trabalho. Assim, contudo, acaba sem ser considerada a sua lógica própria em si, no contexto do valor-dissociação, como relação fundamental fragmentária e contraditória.

Assim, estas atividades também têm de ser submetidas à crítica, tal como o trabalho abstrato (voltaremos a isso mais tarde). Em vez disso, contudo, a vida de dona de casa da fase fordista é explicada de modo reducionista, meramente econômico, num contexto de marxismo tradicional, sobretudo pela redução dos custos do tra- balho mediante a realização do trabalho doméstico. No quadro de referência de uma contradição em processo reformulada, tendo como parâmetro o valor-dissociação como contexto global e o clímax do capitalismo que lhe está associado, também a nova caça às bruxas num contexto de relações tradicionais, por exemplo na África, deveria ser classificada como situação em que se juntam relações tradicionais e relações capitalistas, e não tendo por fundo uma acumulação primitiva, como princípio estrutural central e eterno do capitalismo, que apenas à primeira vista parece plausível.

\section{A colonização como princípio abrangente fundamental até hoje?}

Grande parte dos setores de trabalho intensivo da produção industrial, como assinala acertadamente Federici, é deslocada para países da Europa Oriental e também para países do chamado Terceiro Mundo. Antigas fábricas "socialistas" foram desativadas e completamente privatizadas. Produtos locais deixaram de ser postos à venda. Muitos países do Terceiro Mundo foram obrigados a aderirem aos chamados ajustes estruturais. Empresas do exterior apropriaram-se de recursos destas regiões e dos seus bens de investimento. "Simultaneamente as empresas abriram novos mercados para a venda de seus produtos, ocupando o lugar de produtores/as locais" 
(Federici, 2012, p. 57). Aqui desempenharam um papel decisivo as organizações internacionais (Banco Mundial, Fundo Monetário Internacional (FMI), Organização Mundial do Comércio (OMC) etc.). O Estado de bem-estar social igualmente chegou ao fim.

Assim se chegou também a um deslocamento no interior da relação temporal entre reprodução e acumulação. Com os cortes nos setores da saúde e educação, nas aposentadorias e nos transportes públicos, bem como a introdução de "taxas de utilização", muitos aspectos da reprodução da força de trabalho foram tornados fonte imediata de acumulação (Federici, 2012, p. 58).

Deste modo as atividades reprodutivas foram igualmente financeirizadas.

Também se verifica uma desregulamentação no fato de os/as trabalhadores/as se tornarem precários, no corte das aposentadorias, na redução dos serviços de saúde e de ofertas de educação, mesmo nos países "ricos", resultantes de reformas estruturais, financeirização, guerra e crise da dívida, bem como crise hipotecária; trata-se aqui de "ativar um novo impulso de acumulação" (Federici, 2013 , p. 44). Federici assume que o estado de bem-estar no capitalismo esteve limitado a determinados períodos e a determinados lugares. Aquele foi "claramente resultado de uma interação específica de circunstâncias históricas e pactos de serviços, que chegaram ao fim com as lutas da década de 1960 e o colapso do comunismo" (Federici, 2013, p. 45). As tendências de empobrecimento, entretanto, afetam uma grande parte da população, por exemplo, também na Grécia, Itália, Espanha e EUA. Particular-

mente afetadas são as mulheres mal remuneradas e aquelas negras, que têm de "sustentar" a si mesma e a família. Migram para trabalhar como empregadas domésticas em países distantes, ofertam-se como mães de aluguel, entregam os filhos para adoção, etc. Segundo Federici, por toda parte "é atacada a sua capacidade de controlar a própria reprodução" (Federici, 2013, p. 46).

\begin{abstract}
Constata Federici que
os programas econômicos e sociais que o capital internacional aplicou para derrotar os movimentos de libertação das décadas de 1960 e 1970 conseguem garantir que a expropriação (da terra e de todos os direitos adquiridos), a precariedade do acesso a rendimentos monetários e emprego, uma vida sob o signo da incerteza e insegurança e o agravamento das hierarquias baseadas no racismo e no gênero sejam institucionalizados como condições de produção para as gerações futuras [de tal modo que] por toda a parte a figura do trabalhador se torna a figura do imigrante, do trabalhador deslocado, do refugiado (Federici, 2013 , p. 48 - grifo da autora).
\end{abstract}

Formas antigas de escravidão estão de volta. A expectativa de vida da classe trabalhadora diminui mesmo nos países ricos. No "Terceiro Mundo" expandiu-se o trabalho por diária. Nestas circunstâncias, a classe dos capitalistas, segundo Federici, nos fez acreditar que não haveria alternativa ao capitalismo. Mas, pelo contrário, em todo o mundo se podem ver resistências. "Pois qualquer sistema que não consegue reproduzir a sua força de trabalho, nem tem nada a oferecer de futuro a não ser crises que se repetem, está condenado à queda" (Federici, 2013, p. 50). Apesar de toda a evocação relativamente à reprodução da força de trabalho, segundo Federici é o trabalhador migrante que representa o protótipo da pauperização ca-

\section{gengrafaress}

Revista do Programa de Pós-Graduação em Geografia e do Departamento de Geografia da UFES

Janeiro-Junho, 2019 ISSN 2175-3709 


\section{Gengrafares}

Revista do Programa de Pós-Graduação em Geografia e do Departamento de Geografia da UFES

Janeiro-Junho, 2019 ISSN 2175-3709 pitalista. O inimigo principal é aqui "o capital"!

\section{Resumo intercalar}

Assim como Dörre considera o trabalhador precário subcontratado, inclusive em sua forma migrante, o modelo do explorado na era da globalização, Federici também identifica o trabalhador migrante numa posição idêntica, mas ao contrário de Dörre, recusa terminantemente uma posição reformista. A autora reconhece as relações de trabalho precárias como "desejadas" na medida em que as supõe como "objetivo" do capital. Assume que a "colonização" é um princípio que ainda produz efeitos em termos de teoria da acumulação. Uma crítica do "disciplinamento dos corpos", no sentido da moderna disciplina do trabalho, a qual é reconhecida e bem recebida entre vários/as críticos/as do valor (e da dissociação), adquire em sua abordagem contorno tradicional-operaísta $e$ inclusive no contexto de uma ontologia do trabalho! Enquanto Dörre localiza-se numa tradição sindical do movimento operário, a qual atribui uma grande importância ao Estado, projetando tal ponto de vista aos tempos atuais, tomando como referência Gramsci, hipóteses provenientes da teoria da regulação, da teoria das ondas longas etc., se dedicando de forma passageira à questão das mulheres, dos migrantes e da ecologia à sua revelia, Federici adere notadamente ao ímpeto subjetivista da luta de classes em sentido operaísta.
Tais diferenças, todavia, convergem no que diz respeito a um pensamento fundado numa teoria do ponto de vista e/ou individualismo metodológico, e não em último lugar, com raízes num pensamento tradicional da luta de classes.

É sabido que as bases teóricas de Federici sejam ainda mais áridas que aquelas de Dörre. As verdadeiras referências para ela são Marx, com a separação entre produtores e meios de produção no contexto da acumulação primitiva, bem como a concepção de Dalla Costa, segundo a qual as atividades reprodutivas são necessárias para a formação da força de trabalho, somando-se aí alguns teóricos que recorrem à importância do "Terceiro Mundo" e, por último, Michel Foucault. De resto ela permanece sobretudo no plano descritivo. Nenhum dos dois autores chegam ao ponto essencial da contradição em processo, com todas as suas consequências de um limite sistêmico. Esta perspectiva da contradição em processo, que deve alcançar seu limite objetivo, não tem nada a ver com um ponto de vista otimista sobre o progresso, que Federici censura em Hardt/Negri. Uma análise que assume a existência de um clímax do capitalismo, pelo contrário, se move em um plano objetivo relativamente à teoria da acumulação, em que o desenvolvimento das forças produtivas não é simplesmente compreendido em sentido positivo, como no marxismo tradicional ou nas concepções neo-operaístas; as forças produtivas e as respectivas tecnolo- 
gias também podem ser forças destrutivas.

Federici não contesta completamente a revolução tecnológica e financeira, contudo o decisivo, de seu ponto de vista, é a estratégia de redução de custos movida pelo capital à escala mundial. No entanto desta forma lhe escapa o caráter fetichista da crise mundial, em que a opção pelo rebaixamento dos salários é apenas um momento transitório em direção à superfluidade (ver abaixo). Aqueles que hoje são precários é porque ainda não caíram completamente fora.... Em outras palavras, a precariedade é apenas a ameaça do perigo realmente existente da superfluidade. Esta objeção é válida tanto para Dörre como para Federici. A superfluidade objetiva é a verdadeira categoria, aquela que é decisiva, e não simplesmente a precariedade, que é o mero sentimento disso e que parece ser o verdadeiro em termos subjetivos, exigindo a manutenção incondicional de uma atividade profissional qualquer, nem que seja na forma de um empresariado de si próprio pós-moderno numa sociedade do trabalho concebida como ontológica. O medo de se tornar supérfluo é tão grande que apenas consegue identificar-se teoricamente como o tornar-se precário, revelando o tabu no que diz respeito ao fim absoluto da sociedade do trabalho; este é pura e simplesmente o horror para o precário, que se vê coagido a se posicionar no interior de relações em crise para poder se manter como um ser que se esforça ao máximo. Tudo isto deve ser entendido no quadro de uma crítica geral do valor-dissociação, como crítica que simultaneamente se afirma e se restringe.

Crítica do valor-dissociação, raça, classe, gênero, globalização e decadência do patriarcado capitalista

\section{Pressupostos básicos}

De agora em diante será evidenciada a dinâmica fundamental da relação do valor-dissociação em oposição aos teoremas metafísicos da contínua colonização. Também Kurz parte de uma consideração qualitativa das relações de gênero, com referência à teoria e à crítica do valor-dissociação (com base em Scholz, 2011; 2000). Mesmo se a teoria do valor-dissociação no seu conjunto para ele permanece marginal, como já foi dito, sobretudo no seu último livro Dinheiro sem valor, em última instância toda a sua obra tem de ser localizada no interior de uma abordagem crítica do valor-dissociação. Mas Kurz não supõe de modo nenhum - e esta já era sempre a sua tese central num contexto de crítica do valor - uma classe de capitalistas (personificada), que seja pessoalmente responsável pela exploração da classe trabalhadora (e, no caso de Federici, também pela formação de relações de gênero hierárquicas), mas, sim, um contexto fetichista global.

Kurz escreve sobre a transição para o capitalismo:

Também as relações entre os sexos foram profundamente abaladas no âmbito desta transformação [...]. Tratou-se de um momento essencial da constituição capitalista desde os primórdios da transforma-

\section{gengrafaress}

Revista do Programa de Pós-Graduação em Geografia e do Departamento de Geografia da UFES

Janeiro-Junho, 2019 ISSN 2175-3709 


\section{Gengrafares}

Revista do Programa de Pós-Graduação em Geografia e do Departamento de Geografia da UFES

Janeiro-Junho, 2019

ISSN 2175-3709 ção do dinheiro. Neste processo, todos os elementos da reprodução social não passíveis, ou dificilmente passíveis, de serem representados no âmbito da lógica do dinheiro que também determinava o Estado (do acto de confeccionar a comida ao cuidar dos filhos e até ao "amor") foram retirados do contexto das relações de vinculação ou obrigação existentes até então, mas foram ao mesmo tempo dissociados da nova sociabilidade da mercadoria e delegados nas mulheres [...]. Ao facto de o dinheiro moderno (o capital) e o Estado partilharem uma origem comum no seio da sociedade oficial sobrepôs-se outra coincidência de origens, mais importante, entre a universalidade abstracta (dinheiro e Estado), por um lado, e a dissociação sexual dos momentos da reprodução que nela não têm cabimento, por outro: «Aquilo que está dissociado não é um mero "subsistema" dessa forma (como, por exemplo, o comércio externo, o sistema jurídico ou a política), mas é essencial e constitutivo para a relação global social» [...]. Foi deste modo que surgiram a moderna relação entre os sexos e a família burguesa, que tinham tão pouco que ver com as estruturas anteriores do mesmo nome como o dinheiro transmutado com as suas antigas formas de existência. Também aqui, como é evidente, não se estabeleceu conscientemente uma meta, no sentido de uma relação nova e abrangente e da sua lógica transcendental; os actores agiram, sim, com base em motivos de alcance limitado (por exemplo, a dissolução das antigas representações pessoais patriarcais), os quais, também sob este aspecto, se desenvolviam «nas suas costas» em direcção a outra constelação das relações entre os sexos (Kurz, 2014, p. 119-120).

Kurz também menciona a caça às bruxas como acontecimento crucial:

O processo das atribuições simbólicas e reprodutivas ao sexo feminino decorreu de um modo tão sanguinário e repressivo como o desenraizamento de partes consideráveis da população e a transformação do dinheiro. Prova disso é a bárbara caça às bruxas que se arrastou do século XV até ao início do século XVIII. O patriarcado da Antiguidade e da Idade Média feudal transformou-se, assim, no moderno, mediado pela lógica do dinheiro. A dominação masculina não se terá diluído, mas assumiu outra constituição, quase «objectiva», determinada pela «economia» em formação. $\mathrm{O}$ carácter estruturalmente «masculino» do processo de «desvinculação», associado à mobilização original em torno das armas de fogo, foi inscrito na base do capital nascente mas foi-o, precisamente, como momento dissociado das formas de base e não explicitamente contemplado na reflexão oficial. Depois de a máquina autorreferente da multiplicação do dinheiro estar estabelecida e ter dissociado sexualmente todos os momentos da reprodução que era incapaz de abranger, a «economia» assim criada produziu, graças à sua dinâmica própria, «leis» próprias (Kurz, 2014, p. 120).

Perante este pano de fundo, no fordismo, seriam reduzidos os custos de reprodução da força de trabalho em comparação com a mais-valia, ou seja, houve aumento da extração dessa última, do ponto de vista do capital. Isso significou uma elevação contínua dos salários reais e do poder de compra, resultando em uma otimização das possibilidades de consumo dos assalariados. A formação do modelo de família homem-ganha-pão/ mulher-doméstica veio, assim, paralela à passagem da produção com mais-valia absoluta para a produção com mais-valia relativa, proporcionada pelo desenvolvimento das forças produtivas.

No pós-fordismo, com a revolução microeletrônica e os processos de globalização, estes próprios desdobramentos da relação do valor-dissociação, as instituições da família e do trabalho remunerado se dissolvem. As relações tradicionais entre os gêneros se desfazem sem que desapareçam as hierarquias de gênero. As relações de gênero no patriarcado capitalista asselvajam-se de verdade. O homem como ganha-pão da família e a mulher como dona de casa tornam-se obsoletos. As relações de gênero são agora aparentemente individualizadas, as mulheres são "duplamente socializadas" (cf. Regina Becker-Schmidt), isto é, são igualmente responsáveis pela família e pela profissão, mesmo se agora são liquidados os trabalhos de reprodução cada vez 
mais profissionalizados, por sua vez também por mulheres. Os homens "são transformados em donas de casa" (cf. von Werlhof), na medida em que se movem em relações de emprego precárias. Tendencialmente manifestam-se também no "Primeiro Mundo" relações que conhecemos das favelas dos países do "Terceiro Mundo". As mulheres educam os filhos com a ajuda de familiares mulheres e de vizinhas, os homens vêm e vão, sendo amiúde também sustentados pelas mulheres. Assim continua o patriarcado capitalista, mesmo na sua erosão. As mulheres têm agora de reproduzir uma sociedade que de fato já não pode ser reproduzida, na decadência do patriarcado capitalista, sendo que os homens, com a tendência a "tornarem-se donas de casa", frequentemente se desresponsabilizam. Nisto a situação das mulheres no Terceiro Mundo ou na Europa de Leste apresenta-se sem dúvida mais dramática do que na Alemanha.

O desenvolvimento das forças produtivas e da tecnologia, no entanto, não é mediado apenas materialmente pelas atividades de reprodução "privadas" executadas pelas mulheres, mas também está ligado com a dissociação do feminino na psicologia social e nos símbolos culturais, como mostram diversos estudos (cf., por exemplo, Scheich, 1993). Decisivo aqui é que a dissociação do feminino com relação ao valor (mais-valia) não é "exterior" ao capitalismo, mas a relação do valor-dissociação (mais-valia) é, sim, uma relação basilar dialética, que desde o início constituiu o todo fetichista e o "movimento em si", justamente porque a dissociação do feminino é simultaneamente exterior à relação de valor (de mais-valia).

Por isso, no caso das atividades femininas de reprodução, não se trata simplesmente da reprodução da mercadoria particular força de trabalho (caso em que esta pode depois ser novamente subsumida ao "valor"), pelo contrário, esta dimensão tem a sua lógica própria, que resulta justamente da relação dialético-dinâmica com o valor, e de fato no sentido da reprodução social total no patriarcado capitalista. Nisso a dissociação é tanto pressuposto do valor (da mais-valia) como inversamente. É esta lógica própria, que não em último lugar resulta da separação entre trabalhos produtivos e atividades dissociadas improdutivas, que é preciso ter sempre em conta. É esta dinâmica de valor-dissociação que em última instância possibilita a contradição em processo e gera a queda do capitalismo, pelo que este contexto de valor-dissociação tem de ser reformulado como contexto basilar (cf. também Scholz, 2013). Esta dissociação atravessa todos os planos e domínios, não pode ser simplesmente reduzida à divisão entre esfera privada e esfera pública. Por exemplo, as mulheres na vida profissional continuam a ganhar menos que os homens, mesmo com qualificações equiparáveis. O valor-dissociação (mais-valia) é um contexto basilar objetivo, que constitui o todo social mundial

\section{gengrafaress}

Revista do Programa de Pós-Graduação em Geografia e do Departamento de Geografia da UFES

Janeiro-Junho, 2019 ISSN 2175-3709 


\section{Gengrafaress}

Revista do Programa de Pós-Graduação em Geografia e do Departamento de Geografia da UFES

Janeiro-Junho, 2019 ISSN 2175-3709 como tal e não tem apenas por objeto as relações de gênero em sentido estrito, como um "aspecto" da totalidade social da socialização do "valor". Como tal a crítica do valor-dissociação também dá espaço a diferentes disparidades sociais (ver abaixo).

Mas Federici não consegue ver isto com a sua concepção de colonização, porque esta está revestida de operaísmo e de luta de classes e a partir daí utiliza para as mulheres, os camponeses, os "povos" indígenas, etc., seu ponto de partida sempre subjetivista. Isto se aplica na generalidade também à sua ingénua definição do conceito de natureza. Não é preciso acrescentar que na concepção de colonização de Dörre evidentemente não se consegue encontrar tal abordagem em termos de teoria do valor-dissociação.

\section{Colonização, (re)colonização, globalização?}

Se partimos da contradição em processo e do valor-dissociação, levando em consideração o "mecanismo de compensação relativa" do fordismo, quando a contradição fundamental parecia superada, para se manifestar posteriormente de forma evidente na era da globalização, então não se pode falar deste último como uma recolonização [Re-Kolonialisierung] renovada, no contexto de uma colonização permanente tomada como um princípio capitalista fundamental; pelo contrário, devemos falar de um processo orientado, que em breve chegará ao fim. Federici, no entanto, vê as coisas de um modo completamente diferente: ao invés de reconhecer na financeirização, informatização e a revolução microeletrônica os indícios de uma crise do trabalho abstrato, culminando numa desvalorização do valor engendrada pela contradição em processo no contexto do patriarcado capitalista e o valor-dissociação, a autora admite um aumento do trabalho na atualidade que, além do mais, continuará crescendo indefinidamente.

Ao invés de elevar a "colonização" ao estatuto de essência e lei fundamental (a-histórica) do capitalismo, é preciso qualificar as tendências efetivamente observáveis de "colonização" no contexto de crise do capitalismo, ou seja, do "Colapso da modernização" (Kurz, [1991] 1993), assim como o fenômeno da superfluidade massiva. Sobre isso Kurz já escrevia em 1991:

As ideias de uma "colonização" [Kolonisierung] capitalista do Leste estão claramente orientadas no antigo paradigma esquerdista da "exploração neolonialista" do Sul; em ambos os casos conjura-se como motivo fundamental a absorção de "mão de obra barata" pelo "vampiro" capital. Mas essas ideias tinham seu fundamento real na história de imposição pré-fordista do capital, há muito tempo passada. Mão-de-obra barata como meio principal de acumulação, trabalho forçado e de escravos em produções pouco dispendiosas, na exploração de matérias-primas (mineração, plantações) ou em gigantescos projetos infra-estruturais, tais como a construção de ferrovias e represas, faziam parte (particularmente na União Soviética) das forças impulsoras históricas do capital, isto é, de sua "acumulação primitiva”. Quem refere essas forças e esses motivos sem cerimônias ao atual sistema global está vivendo ideologicamente no passado e deixa de ver os potenciais entrementes nascidos da penetração das ciências e o nível daí resultante da produtividade (Kurz, 1993, p. 166).

A acumulação primitiva 
ocorrida nos países do Terceiro Mundo, comparável com aquela registada cerca de 400 anos antes em alguns países europeus, ocorreu em grande medida após a Segunda Guerra Mundial, quando o nível de socialização (capitalista) mundial já se encontrava fortemente desenvolvido (a não ser em alguns territórios nos quais restos de uma economia de subsistência tradicional tinham se mantido, não obstante a brutal fase de colonização) ${ }^{12}$. Por isso, em relação à "modernização retardatária" dos Estados do Terceiro Mundo, trata-se por assim dizer de um tiro que saiu pela culatra, porque eles já não conseguem realizar uma acumulação primitiva no contexto de um "novo modelo de acumulação" à escala global (Kurz, 1993, p. 193197). A industrialização "ficou parada na metade do caminho, isto é, depois de desarraigar as massas, deixou de integrá-las na moderna máquina de exploração em empresas" (Kurz, 1993, p. 194), restringindo-se a determinadas regiões (Kurz, 1993, p. 194). No essencial, tais tendências prosseguem no processo de globalização das últimas décadas.

Tal como Federici concebe os atuais processos de globalização equivocadamente como "recolonização" [Rekolonialisierung], há igualmente posições que simplesmente negam a dimensão mundial dos processos de globalização. Kurz também se opõe a tais posições: não em último lugar

no curso da globalização [...] foram constituídas de modo completamente novo "zonas econômicas especiais" e sobretudo zonas de processamento de exportação (ZPE) pelas quais circula o ca- pital transnacional. A própria designação "zona" aponta para o caráter extraterritorial da crise de toda a organização. A extraterritorialidade consiste em condições especiais relativas à tributação, licenciamento, direitos do trabalho etc., as quais exprimem a crescente renúncia do Estado nacional à sua capacidade de regulação. Tais zonas se expandem de forma célere, enquanto a coerência da economia nacional se esboroa e simultaneamente aumentam as zonas de completa paralisia e abandono (Kurz, 2005, p. 182).

Note-se que Kurz designa estas zonas econômicas especiais com o termo "extraterritorialidade" e não com o conceito de "colonização". Em outras palavras, estas zonas têm mais a ver com "estado de exceção" que com a incorporação pelo sistema de regiões externas ao capitalismo, no sentido de uma permanente auto-renovação (ver abaixo).

Kurz parte essencialmente do fato

de que a globalização atinge cada vez
mais países - todavia como processo de
crise interna, com divisão econômico-
-social. A dimensão da penetração trans-
nacional pode ser mais ou menos forte,
mas frequentemente se realiza apenas em
doses homeopáticas, enquanto a maioria
do espaço é abandonado à desintegração.
Ou seja, por um lado toda a periferia glo-
bal é atingida no seu conjunto, por outro,
tal se realiza de forma completamente
irregular (Kurz, 2005, p. 182).

Sem embargo, é preciso aqui notar: "No interior da compressão de determinadas regiões ao processo de globalização ocorrem constantes deslocamentos e reagrupamentos à escala planetária, continental e nacional" (Kurz, 2005, p. 179). Isto aplica-se também aos chamados países em desenvolvimento e aos BRICS, aspecto que até a redação da revista Prokla constata numa chamada de artigos de 2014:

as perspectivas de desenvolvimento dos BRICS não são definitivamente claras: se Estados como a Índia e o Brasil há pouco tempo eram considerados casos de sucesso, mais recentemente há indícios de que estes países apresentam sinais de crise. A Rússia, há poucos anos uma po-

\section{Gengrafaress}

Revista do Programa de Pós-Graduação em Geografia e do Departamento de Geografia da UFES

Janeiro-Junho, 2019 ISSN 2175-3709 


\section{GenGrafaress}

Revista do Programa de Pós-Graduação em Geografia e do Departamento de Geografia da UFES

Janeiro-Junho, 2019 ISSN 2175-3709 tência líder, é hoje considerada um país em desenvolvimento, cuja política se vê obrigada a criar uma nova esfera de influ-

ência (Redação da Prokla, 2014).

Entretanto, se pode constatar por toda a parte que os países em desenvolvimento se encontram numa crise profunda.

Pelo contrário, Federici compreende os processos cegos da globalização - ceterum censeo - como vontade de colonização por parte do "capital" no contexto de uma "acumulação primitiva" global e permanente, pressupondo uma infindável continuidade da extração de trabalho excedente.

Partindo da crítica do valor-dissociação, os atuais processos de globalização

não ocorrem na senda de um movimento ascendente do capitalismo global, mas descrevem a trajetória de um movimento descendente. Por isso predomina na formação estrutural da "auto-similaridade" global a tendência negativa, resultando na manutenção da antiga distância entre o centro e a periferia, mas no interior de uma história comum de crise e desintegração [...]. A "auto-similaridade" do sistema mundial permanece superficial, porque se apresenta no centro e na periferia numa densidade completamente diferente [...]. Por isso se expandem [...] os processos de desintegração social nos países periféricos de forma mais célere que nos países centrais do capitalismo (Kurz, 2005, p. 109)

Os fenômenos de desintegração dos países da periferia, porém, são justamente um sério aviso aos países do "Primeiro Mundo", como há muito se pode ver (Kurz 1993, p. 165197). A lógica da contradição em processo quando alcança seu "limite interno" na forma do crédito, financeirização e economia de déficit, mostra-se empiricamente em relações de modo nenhum tornadas iguais nem da mesma empiria; a história colonial desdobra-se no presente, determinando-o, e nesse sentido é preciso concor- dar com Federici; mas é precisamente por essa razão que as mudanças qualitativas recentes observadas à escala mundial já não podem ser compreendidas à luz de uma teoria da colonização, na medida em que esta última parte das relações pregressas existentes nas antigas colônias.

Deste modo torna-se visível um etnocentrismo invertido em Federici: para a autora as margens do capitalismo, nomeadamente as colônias, os povos indígenas, ou mesmo as mulheres da "cultura dominante" (Birgit Rommelspacher, ver abaixo) são transformadas em "centro estratégico", todavia à luz de um marxismo do movimento operário transformado e que, destarte, encontra-se impelido a se apoiar, entre outros, no pressuposto da colonização buscando alcançar alguma legitimação. Neste particular Kurz constata o seguinte para os chamados países emergentes como a China:

Aqui nenhum território é efetivamente industrializado, pelo contrário, ocorrem atividades econômicas desterritorializadas, pontuais, cuja coerência não é formada pela China e tampouco por outros países entendidos enquanto economias nacionais, mas exclusivamente por funções particulares da economia empresarial (Kurz 2005, 128). ${ }^{13}$

Isto implica, ainda segundo Kurz, que:

Nas condições da terceira revolução industrial, que tornou realidade esta imediaticidade do mercado mundial, as forças produtivas e os meios de produção da maior parte do mundo são descartados por falta de rentabilidade em termos empresariais, o que não significa que as pessoas possam prescindir da forma capitalista (visto que constitui sua própria forma interior de sujeito), que por sua vez é também determinada pela moderna relação entre os sexos, ou seja, é sexualmente modificada. Já onde os meios de produção não são pura e simplesmente descartados (não em último lugar as terras agrícolas férteis), tais sofrem uma reorientação forçada para o mercado 
mundial universal, o que significa, por exemplo, no âmbito do agronegócio global, a produção pouco exigente, em termos de qualificação da força de trabalho, de produtos de alta tecnologia, bens de luxo como flores cortadas ou alimentos selecionados para os centros ocidentais, enquanto a população local é expulsa de suas terras e privada de seus recursos vitais, que não (ou já não) podem ser representados economicamente sob a forma do valor e integrados à produção para o mercado mundial devido ao novo patamar das forças produtivas, sequer de forma meramente repressiva como "hands" [trabalhadores manuais]. É um fato que os fluxos de mercadorias e de dinheiro, os quais representam a produção agrária marginalizada ou situações pontuais de superexploração da força de trabalho, são de uma dimensão inegavelmente reduzida face à totalidade do produto global e, em especial, face ao volume do capital financeiro vazio de conteúdo; mas é precisamente nesta dimensão relativamente microscópica da criação de riqueza 'válida' a nível mundial que desaparece a vida de massas populacionais enormes de 'supérfluos'. A riqueza (ela própria apenas abstrata e destrutiva) dos países centrais do Ocidente não depende da massa de flores provenientes da Colômbia ou da África central cortadas por trabalhadores superexplorados, levadas para as metrópoles por avião; por outro lado, é em nome dessa meia dúzia de flores cortadas que populações inteiras são socialmente sacrificadas, precisamente porque a existência no âmbito do mercado mundial está ferreamente estabelecida como a única forma de existência possível (Kurz, 2003, p. 66 e ss.).

A extração de coltan e outras matérias primas, tal como a exploração de trabalho para a atual produção de celulares, são algo diferente dos tempos da colonização [Kolonialisierung]. As "flores cortadas" em Kurz funcionam apenas como uma metáfora da riqueza superficial do Ocidente. A economia atual ocorre majoritariamente em transações no mercado financeiro e em cadeias transnacionais de criação de valor, isto é, em investimentos de racionalização, explorando a redução de custos. É justamente uma riqueza mercantil superficial que por maioria de razão exige aqui tal exploração exaustiva e que ocorram deslocalizações do investimento para outras partes do mundo condicionadas pela racionalização, nas quais depois é exercida uma exploração maciça da força de trabalho e que no seu conjunto diminui a massa de valor e o trabalho abstrato na sua "substância material abstrata". Tais relações de exploração, no entanto, devem ser consideradas à escala da totalidade social (mundial) constituída, o que indica que elas se reproduzem sobretudo mediadas pelo crédito e não em último lugar financiadas por meio de um circuito de déficit. Mesmo os alimentos básicos são hoje patenteados e tornados objetos de especulação. Neste contexto as matérias primas continuam a ser exploradas como antes, mas também em formas novas como o fracking ${ }^{14}$, com as respectivas consequências ecológicas, e nesse sentido pode-se falar em "colonizações". Igualmente pode-se falar hoje em "segurança de reservas estratégicas de matérias primas", visto que a segurança de matérias primas fósseis, dada sua importância para todo o modo de vida capitalista, assume um papel crescentemente mais importante que antes, num contexto de sua gradual escassez (Kurz, 2003, p. 103).

Naturalmente que uma nova rodada de privatização de equipamentos públicos tampouco pode ser compreendida como uma nova colonização em sentido estrito - como sugere Dörre e também Federici. Trata-se de uma reestruturação no interior da socialização patriarcal capitalista que, após a fase fordista do "mecanismo de compensa-

\section{gengrafaress}

Revista do Programa de Pós-Graduação em Geografia e do Departamento de Geografia da UFES

Janeiro-Junho, 2019

ISSN 2175-3709 


\section{Gentrafaress}

Revista do Programa de Pós-Graduação em Geografia e do Departamento de Geografia da UFES

Janeiro-Junho, 2019 ISSN 2175-3709 ção relativa", anuncia agora o fim do capitalismo. Os atuais movimentos de refugiados expressam aqui uma linguagem clara. Desta forma o trabalhador subcontratado / trabalhador migrante / refugiado, explorado de fato de uma maneira nova e precária, não é porventura uma nova versão do trabalhador/proletário, mas a expressão de sua crise; uma forma de exploração de novo tipo que a contradição em processo do capital assume neste momento, compreendida aqui como uma determinada fase de decadência do capitalismo. É verdade que desde a década de 1990 ocorreu uma nova fase de expansão da produção de mais-valia absoluta à escala mundial, todavia isto já era uma evidência do limite interno da produção de mais-valia no contexto capitalista global, apoiada na expansão de cortes salariais e aumento das jornadas de trabalho nos países do centro (cf. Kurz 2014, p. 265-289). Mais cedo ou mais tarde, no entanto, tais tendências deverão ser alavancadas por novos saltos de racionalização dos processos produtivos, como se vê, por exemplo, na discussão do fenômeno "Indústria 4.0", mesmo que ambas as tendências se desenvolvam paralelamente durante algum tempo. Os seres humanos serão simplesmente descartados. Portanto é preciso formular as novas disparidades sociais, também na dimensão global, para além das categorias do velho movimento operário (cf. por exemplo, Scholz, 2005). Nisto o marxismo ocidental e o marxismo oriental não se encontram tão distantes como se sugere ${ }^{15}$. Em resumo, pode-se dizer que as enormes manchas em branco no Terceiro Mundo mostram que os seres humanos concretos há muito são tão supérfluos quanto aqueles que atualmente se julgam precários na Alemanha. Como empresários de si mesmos há algum tempo pressentem que não serão poupados a esse destino, e que se encontram ameaçados de uma paralisação absoluta (ver Grécia, etc.), o que, entretanto, (pretendem) ignorar - a Grécia e os Estados a oeste dos Balcãs, abalados pela crise, como Estados terceiros supostamente seguros, são obrigados a acolher refugiados quando já se configuram como regiões das quais as pessoas fogem, dada a perspectiva de superfluidade à qual já se encontram.

Administração da crise nacional e internacional, obsolescência do trabalho abstrato, ruína da periferia e guerra civil mundial

Para concluir, pode-se constatar mais uma vez:

É [...] uma ilusão de ótica ver aqui uma reindustrialização com base em novas vias orientadas para a exportação, que poderiam conduzir para além da antiga divisão de funções em que os países periféricos foram degradados a fornecedores de matérias primas. Pelo contrário, a antiga degradação é apenas completada ou substituída por uma nova, nomeadamente a utilização de opções baratas, desconexas, para a economia empresarial transnacional, enquanto o corpo da economia nacional se desmorona (Kurz, 2005, p. 128).

Como se viu, o capitalismo determinado pelo mercado financeiro, essencialmente mediado pelo crédito e caracterizado por um circuito de déficit, 
já não pode por si só "arranjar" um novo modelo de acumulação, após o fim do paradigma da produção. Ele cria constantemente "bolhas financeiras" que têm de estourar mais cedo ou mais tarde. Mesmo uma potência até aqui considerada hipersoberana, como a China, está passando por isso (cf. Konicz, 2015).

Em seguida, será abordado, pelo menos ligeiramente, a relação entre administração da crise nacional e internacional, a obsolescência do trabalho abstrato, o desmoronamento da periferia e as guerras civis mundiais, que até agora não foram abordadas muito bem e que em Dörre e Federici aparecem exclusivamente como dimensões da "colonização", na medida em que ambos recuam perante a crise fundamental do patriarcado capitalista, que não pode ser evitada por qualquer classe dominante ou subalterna (revolucionária).

Neste contexto, Kurz também contradiz todas as teorias que continuam a ver o Estado nacional como base reguladora primária e identificam neste contexto possibilidades de ordem mundial - seja na dimensão média, seja na dimensão macro da globalização - uma ilusão que para alguns também consiste hoje em ver uma decadência mais ou menos provável do capitalismo, que, ainda assim, deve ser dominada de modo imanente, tanto quanto possível.

Em vez disso, Kurz vê a administração da crise nacional e internacional como momento característico da atual sociali- zação mundial. As guerras de ordenamento mundial das últimas décadas não servem apenas para a segurança das reservas de matérias primas (não em último lugar o petróleo) e dos mecanismos de transferência capitalistas, a fim de garantirem uma criação (reduzida) de valor à reprodução capitalista. Escreve Kurz, já no ano de 2005:

Na periferia os processos de colapso em parte já levaram mesmo à dissolução do próprio aparato de violência nacional em estruturas de senhores da guerra e subculturas terroristas. O "imperialismo global ideal" (no sentido do Ocidente e dos EUA criadores da ordem, R. S.) não tem aqui qualquer perspectiva de reconstrução das possibilidades de acumulação; limita-se a tentar reconstituir os aparelhos nacionais de violência e de administração de pessoas (como no Iraque, no Afeganistão ou na antiga Iugoslávia) e onde já nada mais funciona passa à política dos protetorados, a campos de detenção e, por fim, à aniquilação de pessoas em larga escala [...]. De certa maneira, parece repetir-se aqui a história da constituição da moderna sociedade burguesa. No princípio era o estado de necessidade, a submissão do material humano à valorização do capital, como descreveram Marx no capítulo sobre a "acumulação primitiva" e Foucault, fenomenologicamente, no que respeita à história de disciplinamento para as exigências do "trabalho abstrato". O núcleo violento de todo o direito burguês, incluindo os direitos humanos, surge desvendado. No entanto, há uma diferença decisiva. O capitalismo inicial, num nível de produtividade relativamente baixo, ainda tinha à sua frente a história da acumulação e imposição do capital. O capitalismo de crise da terceira revolução industrial, num nível enormemente elevado e já não integrável nas suas formas, tem aquela história atrás de si. Por isso é fundamentalmente errado descrever a atual administração da crise planetária como nacional, como renovada "colonização capitalista", como faz grande parte da esquerda (para assim poder responder de alguma forma, repetindo os seus paradigmas tornados obsoletos). "Colonização" implicaria que aqui se tratasse de mobilizar recursos e, sobretudo, de força de trabalho para a renovação do movimento de acumulação. O caso é exatamente o contrário: para a administração da crise trata-se de desmobilizar recursos e força de trabalho, porque o capital mundial, no nível atingido do standard de produtividade e rentabilidade, já não é capaz de uma reabsorção alargada de capacidades produtivas, na forma de "trabalho abstrato". O novo colonialismo de crise externo do Ocidente visa apenas manter

\section{gengrafaress}

Revista do Programa de Pós-Graduação em Geografia e do Departamento de Geografia da UFES

Janeiro-Junho, 2019 ISSN 2175-3709 


\section{Gengrafares}

Revista do Programa de Pós-Graduação em Geografia e do Departamento de Geografia da UFES

Janeiro-Junho, 2019 ISSN 2175-3709 na ordem as massas de seres humanos inutilizáveis nas regiões em colapso. $\mathrm{O}$ novo colonialismo de crise interno dos aparelhos nacionais de administração de pessoas, por outro lado, visa apenas apaziguar repressivamente a desmobilização da força de trabalho "própria" e dar-lhe uma forma contínua de geri-la. O que se procura é a administração da pobreza até à exaustão e não a renovação reguladora de "projetos" sociais globais. O capitalismo transnacional já não está simplesmente em posição disso (Kurz, 2005, p. 457 e ss.).

Correspondentemente também estão, entre outros,

condenados ao fracasso os projetos induzidos pelo Estado com base em baixos salários e trabalho comunitário obrigatório, pois não podem constituir nenhuma base de acumulação, pelo contrário, representam apenas uma fase de transição para novas camadas de párias (Kurz, 2003, p. 357) ${ }^{16}$

A Pax Americana, portanto, já não é qualquer construção imperialista, no sentido de assegurar uma hegemonia nacional, mas caracteriza a aglomeração de capital multinacional, para além de um centro de dominação nacional. Imperialismos securitários funcionam há muito, por exemplo, para trabalhadores "estrangeiros" mexicanos nos EUA, e se mostram atualmente de uma maneira particular nos movimentos de refugiados que a fortaleza Europa procura desesperadamente conter, aplicando-se especialmente aos/às migrantes "supérfluos/as", com menos qualificações. Não seria de admirar se a "colonização" fosse novamente virada à direita: "nós" estamos sendo inundados e colonizados por eles, não somos "nós" que estamos a esmagá-los.

Federici mais uma vez vê as coisas justamente ao contrário, ainda que fale frequentemente de encerramentos e da perda de cada vez mais postos de trabalho:

Temos, no entanto, de rejeitar a conclu- são de que a indiferença que a classe capitalista internacional mostra perante a perda de vidas humanas, provocada pela globalização, prova que o capital já não precisa de mais trabalho vivo, de modo que estaríamos cada vez mais rodeados de populações "supérfluas". De fato, a destruição da vida humana em grande escala é desde a formação do capitalismo uma das suas componentes estruturais. É a contrapartida necessária da acumulação de força de trabalho, o que constitui sempre inevitavelmente um processo violento. As "crises de reprodução" periódicas, que presenciamos durante as últimas décadas na África, se assentam nesta dialética de acumulação e destruição de força de trabalho (Federici, 2012, p. 66 e ss.).

Ela coloca neste contexto relações de trabalho precárias, escravidão infantil, tráfico de órgãos etc. Ora, de fato, o fetiche do capital, para obter valor (mais-valia), por um lado, depende da força de trabalho humana, por outro lado, neste fim-em-si irracional, ele abstrai da obtenção de mais-valia de cada ser humano. Federici, no entanto, força esta dialética, ainda colorida pelo antigo marxismo das classes, de forma a-histórica, a fim de não ter que ver a atual obsolescência do trabalho abstrato e o desmoronamento do capitalismo.

Destaca-se que anomia e processos de asselvajamento quase não mereçam a atenção de Federicici ${ }^{17}$. A miséria do mundo atual é para Federici o resultado do capital, no sentido da classe capitalista. Gerd Bedszent, pelo contrário, escreve, por exemplo:

[As] regiões "libertadas" da ditadura transformam-se [...], na sua maioria, rapidamente em palco de milícias étnicas, guerreiros religiosos e bandos armados de criminosos perfeitamente vulgares. Um exemplo particularmente crasso é o Iraque, em que a guerra de ordenamento mundial de 2003 levou de fato à rápida queda do ditador Saddam Hussein, mas o país, na sequência da crescente destruição da economia e das infraestruturas públicas, caiu numa interminável guerra civil entre milícias religiosas combatendo entre si [...]. Após o colapso das eco- 
nomias nacionais dos Estados periféricos, restam frequentemente localizações ainda mais isoladas de criação de valor, a maioria das vezes extração de matérias primas ou empresas agrárias organizadas industrialmente. Estas localizações estão cada vez mais desligadas da economia real das respectivas regiões e funcionam já apenas como fornecedoras da economia das metrópoles capitalistas (Bedszent, 2014, p. 19 e ss.).

Neste particular, Bedszent constata que:

Na sequência do desmoronamento do Estado ocorrem frequentemente lutas sangrentas pelo controle das últimas fontes de criação duradoura de valor entre os restos do exército estatal, movimentos rebeldes, milícias étnicas e guerreiros religiosos. O partido em conflito que se afirma em cada região pode sacar às empresas produtivas dinheiro na forma de licenças de venda, impostos ou pura extorsão, para assim se financiar. Se as lutas caem depois fora de controle, de tal modo que o fluxo de matérias primas das regiões em luta fica seriamente ameaçado, voltam a ser pedidas novas guerras de ordenamento mundial do Ocidente (Bedszent, 2014, p. 20).

Contudo: "A ausência de estatalidade [...] não pode ser reconstruída pela pura força militar" (Bedszent, 2014, p. 20). De resto, também cresce aqui a violência masculina. Hoje, em tempos de uma situação de guerra civil mundial realmente agudizada, em que, de fato, não pode deixar de se ver que ela arde em todos os cantos da Terra, de um contínuo crescimento da superfluidade, em que a opção dos baixos salários, do financiamento a crédito, etc., operam somente uma fase de transição enquanto se tornam obsoletos o trabalho abstrato e o trabalho doméstico, essas avaliações de desmoronamento estão mais que confirmadas.

Aqui se revelou a impotência do Ocidente, ou dos EUA, que já há muito tempo não conseguem se apresentar como megaautoridades soberanas. $\mathrm{O}$ cenário de uma guerra civil mundial assumiu hoje contornos ainda mais claros: pense-se na zona árabe, no Mali, na Nigéria etc. Na realidade não é preciso nenhuma lista, basta ver as notícias diárias. É de presumir que no caso do conflito Rússia-Ucrânia se pretenda simular mais uma vez o conflito União Soviética/Rússia versus Ocidente, sendo que ele tem um caráter completamente diferente, por causa da nova situação de desmoronamento mundial.

Tanto a Rússia, bem como a China, os EUA e a Zona do Euro estão ameaçados por cenários de ruína próprios, mesmo se até agora continuam "algumas vezes a subir, outras vezes a descer" (cf. Kurz, 2013a). Por isso, o conflito Rússia-Ucrânia não é de modo nenhum uma mera tempestade em copo d'água. Por outro lado, ele não sugere simplesmente um antigo cenário de conflito, que pudesse provavelmente se desenvolver como grande "contradição principal" na perspectiva geopolítica. A economia mundial está, entretanto, tão mediada consigo mesma, que ela passa por cima das "economias nacionais" individuais. Também o eixo Rússia-China-Índia, por exemplo, que mais uma vez se pretende afirmar em termos geopolíticos, é afetado por isso. Assim, não deveríamos nos deixar impressionar com a intervenção "de Putin" no conflito da Síria.

Neste contexto, o tema da "Indústria 4.0", muito discutido no momento, que considera uma robotização até então desconhecida e a importância da "inteligência artificial", está hoje a fazer concorrência com

\section{gengrafaress}

Revista do Programa de Pós-Graduação em Geografia e do Departamento de Geografia da UFES

Janeiro-Junho, 2019

ISSN 2175-3709 


\section{GenGrafarest}

Revista do Programa de Pós-Graduação em Geografia e do Departamento de Geografia da UFES

Janeiro-Junho, 2019 ISSN 2175-3709 as recentes teorias da colonização e a afirmação do alargamento estrutural mundial da exploração de força de trabalho - mesmo na opção de baixos salários e independentemente do fato de se tratar de trabalhos na indústria ou nos serviços (ainda que questões técnicas possam permanecer em aberto por mais tempo, como, por exemplo, os automóveis de condução automática).

Mesmo que se conceba esta inovação mais uma vez como colonização, no sentido da expropriação da segurança fordista, como o faz Dörre, isto afeta não só o "Primeiro", mas também o "Terceiro Mundo", tal como os países emergentes, sendo que a aproximação ao "Terceiro Mundo" já vai bem avançada em alguns países do sul da Europa. Como já foi dito, a poupança de trabalho e a expansão de trabalho poderão aqui entrar em corrida ainda por algum tempo, num quadro que se vai tornando cada vez mais inseguro. Corrida que, no entanto, acabará em prejuízo do "trabalho", podendo os prováveis crashes financeiros acelerar ainda mais este processo. A forma exata de desenvolvimento da crise fundamental não pode, contudo, ser antecipada; tão pouco se pode indicar a data exata em que o capitalismo colapsa, como gostariam alguns que entendem este colapso no sentido de um enfarte cardíaco repentino (cf. Kurz, 2014, p. 321-332.). Trata-se de um processo mais longo, que já podia ser percebido ao menos desde a década de 1980, mas que ainda não aconteceu, como hoje se pode dizer retrospectivamente (ver Kurz, [1986] 2018).

Mesmo que ainda venha mais uma "onda longa", seja ela curta ou comprida, o fim do patriarcado capitalista deverá ser confirmado, o que obviamente não tem de significar incondicionalmente um fim emancipatório. No entanto, a questão das forças produtivas, e não só ela, já é sempre a questão da relação de valor-dissociação como contexto basilar em si contraditório que, no sentido de uma abordagem dialética negativa, difere do antigo entendimento da contradição no sentido de Marx.

Sobre a relação entre crítica do valor-dissociação, "raça", "classe", gênero, globalização e teorias da colonização.

PDe acordo com Federici há um processo contínuo e ubíquo de ocupação /colonização [Koliniarisierung], inclusive de cada pessoa individualmente, uma vez que "o capital", com sua fome insaciável, está sempre interessado na exploração da força de trabalho. Tal asserção vale igualmente para a era da globalização, insinuando que "o capital" esteja interessado de forma vital na expansão do "proletariado mundial". Ainda de acordo com a autora os sujeitos são mulheres, camponeses, povos indígenas, trabalhadores, trabalhadores precários deslocados etc. Diferentes regimes de disciplinamento geram uma acumulação de diferenças e hierarquias, de tal modo que o capitalismo é 
sofrido e experimentado a partir de lugares específicos. Diferentes disparidades sociais, observadas sob a categoria da colonização, se transformam em uma acumulação primitiva perpétua, e desta forma são equiparadas em suas qualidades particulares por meio de um procedimento de lógica identitária. Em outras palavras, Federici parte do princípio de que as mulheres, os camponeses, os povos indígenas e inclusive a natureza, criam "valor".

A teoria do valor-dissociação, pelo contrário, parte do princípio de que o feminino foi dissociado do valor (mais-valia), do trabalho abstrato e do sujeito masculino, sendo por sua vez investido às mulheres (seja na forma das atividades de cuidado ou igualmente nas qualidades como sensibilidade, emotividade, fraqueza de carácter, entre outras), carregando consigo a divisão entre um domínio público e um domínio privado e suas correspondentes conotações sexuais hierárquicas. As modernas ideias de gênero espalharam-se assim por todo o globo. Todavia o valor-dissociação não pode ficar preso à divisão destes domínios e por isso ele atravessa todos os planos e domínios da sociedade, tendo igualmente um lado sociocultural e sociopsicológico. Compreendê-lo como um processo significa dizer que ele não é sempre o mesmo. Ou seja, adquire uma feição diferente na pós-modernidade daquela relativamente à modernidade. As mulheres são atualmente "duplamente socializadas", pois se desfaz o papel dos homens como "chefes de família". Esta dissociação do feminino deve ser, portanto, considerada o pressuposto dos desdobramentos da contradição em processo que leva o trabalho abstrato à sua obsolescência perante o crescimento extraordinário da riqueza material no clímax do capitalismo. $\mathrm{O}$ fantasma de uma feminilidade irracional não foi apenas decisivo no desenvolvimento das ciências naturais e das forças produtivas, mas revelou-se igualmente crucial na formação da família nuclear durante o fordismo e suas respectivas atribuições de gênero, a qual se encontra hoje em decadência na sua forma tradicional. Ou seja, valor e dissociação condicionam-se um ao outro: o primeiro é o pressuposto do segundo e vice-versa, o primado não é do valor.

O que não significa afirmar que a relação hierárquica entre os gêneros seja a contradição principal - mesmo levando em consideração que a dissociação do feminino com relação ao valor teve por consequência, no competente entendimento da ciência, que o mundo da vida, o contingente, o não compreensível analítica e conceitualmente, e que em grande medida continua a ser associado ao feminino, foi negligenciado, desprezado e considerado inferior, não apenas na economia e na política, mas igualmente na ciência. Dominante foi um pensamento classificador que não levou e não leva em consideração a qualidade particular, a "coisa" em si não abarcada no conceito, incapaz de suportar as rupturas, ambivalências e diferenças que

\section{gengrafaress \\ Revista do Programa de Pós-Graduação em Geografia e do Departamento de Geografia da UFES \\ Janeiro-Junho, 2019 ISSN 2175-3709}




\section{gengrafaress}

Revista do Programa de Pós-Graduação em Geografia e do Departamento de Geografia da UFES

Janeiro-Junho, 2019 ISSN 2175-3709 lhe estão associadas, absolutizando a identidade e negando a não-identidade (cf. Adorno, 1966). O reconhecimento desta condição pela crítica do valor-dissociação deve resultar na sustentação da seguinte acrobacia que consiste em, de um lado, se afirmar como contexto fundamental e, de outro, admitir aquilo que não pode ser abarcado pelo seu conceito, em oposição ao pensamento androcêntrico universalista. Em outras palavras, a crítica do valor-dissociação só pode se manter na medida em que esteja pronta a igualmente desmentir-se a si mesma. O que não significa que ela deva se confundir ao lado das diferenças, ambivalências, rupturas, dessincronizações etc., quase como numa flutuação livre; pelo contrário, ela deve asseverar estas últimas, por assim dizer, em si mesmas, fazendo valer simultaneamente a sua qualidade própria. Por isso racismo, anti-semitismo e anticiganismo não podem ser derivados do valor-dissociação, enquanto contexto social basilar, assim como a dissociação não pode ser derivada do valor. Em outras palavras, isto significa dizer que a dissociação é de certa maneira o paradoxo de um conceito não idêntico, inclusive tomado em sua dinâmica histórica.

Já em 1995 Birgit Rommelspacher, no que concerne à equiparação de mulheres, "selvagens" e colonialismo, escreveu: as mulheres são discriminadas do mesmo modo que as minorias étnicas, pois o racismo colonial seguiu no essencial a mesma lógica que o sexismo. Esta lógica funciona nas construções da "mulher" e do "selvagem", que muitas vezes se sobrepõem (Rommelspacher, 1995, p. 106)
Daí retira ela a consequência:

Uma tal constatação relativa aos pontos comuns deveria realmente levantar a questão das diferenças. Mas via de regra esta questão não é colocada. Tal vale sobretudo para os debates influenciados pelo ecofeminismo, que destacam a ligação entre a exploração dos povos colonizados e a exploração das mulheres como "matéria prima". A apropriação colonial de terra e recursos naturais é equiparada à colonização das mulheres nas nações industrializadas. Aqui se assume a equiparação não só das imagens, mas também dos princípios de exploração e dominação política (Rommelspacher, 1995, p. 106)

Não é difícil perceber que tal equiparação também se encontra em Federici e significa, à luz da crítica da colonização, aqui apresentada, que a crítica do valor-dissociação tem de reconhecer as estruturas sexistas, racistas, anti-semitas e anticiganas na sua própria lógica e denunciá-las publicamente, assim como as disparidades econômicas, mesmo que referidas à queda das classes médias formadas na fase fordista (que hoje se colocam no centro das atenções, cheias de autocomiseração). Isto igualmente se aplica à composição específica de relações sociais presentes em diferentes regiões do mundo, compreendendo-as em suas particularidades concretas, até contextos micro como, por exemplo, identidades híbridas e um acúmulo de formas de discriminação sobre indivíduos isolados, tendo por pano de fundo um devir histórico no contexto patriarcal-capitalista global (sobre isto cf. Scholz 2005 e 2008). Ao contrário de críticas do valor hoje muito divulgadas, a crítica do valor-dissociação assume, portanto, a relevância das disparidades e hierarquias econômicas e sociais, bem como a necessidade da sua 
análise. A crítica meramente distributiva do valor representada pelo marxismo tradicional não deve conduzir a que o bebê seja jogado fora junto com a água do banho; pelo contrário, é necessário ter em conta as dimensões de desigualdade, para além do entendimento marxista do movimento operário relativo a este aspecto. E nesse sentido não se deve evitar os planos médio e micro, tampouco as perspectivas mais próximas da empiria, as quais não devem ser tratadas como inferiores, face à teoria macro do valor-dissociação (cf. Scholz, 2009a). De acordo com a teoria da colonização apresentada por Federici, ocorre uma "totalização" (Hedwig Dohm), uma vez que sua afirmação sobre a permanência da acumulação primitiva tende a subsumir tudo em conceitos fenomenológicos como expropriação, cercamento, ocupação de terras, exibindo uma determinação difusa da reprodução social.

Em Federici a referência aos sujeitos discriminados se dá de forma independente de quaisquer mediações, no modus da pura imediaticidade. De acordo com sua argumentação não há lugar para uma determinação estrutural da "raça", do gênero e das disparidades econômicas; o que faz com que tais sejam tratadas e analisadas sobretudo num plano descritivo. Federici tampouco se dedica a criticar as transformações ocorridas no plano subjetivo, na forma de identidades flexíveis compulsivas, inapelavelmente exigidas pelo turbocapitalismo, não apenas porque para ela todos os sujeitos têm de ser resistentes, mas igualmente porque ela hipostasia e invoca a priori a subjetividade do movimento, inclusive transformando-a em fundamento e motor do desenvolvimento capitalista. Como operaísta, Federici simplesmente ignora os momentos e potenciais de barbárie nos movimentos sociais "de resistência".

A crítica do valor-dissociação não enaltece as diferenças e tampouco as deixa indeterminadas como nas teorias pós-modernas, até o ponto em que ela própria se dissolve como contexto basilar. Ao contrário de um pensamento pós-moderno da diferença, para a crítica do valor-dissociação não se trata da qualidade de uma determinada coisa, mas pelo contrário, de insistir paradoxalmente numa totalidade, pressuposta tanto aos indivíduos como aos grupos sociais, quer queira, quer não. A categoria abrangente do valor-dissociação, como contexto basilar, só se torna isto à medida que ela própria deve se afirmar de maneira absoluta, engendrando diferenças, contradições e desigualdades, o que está igualmente compreendido com relação ao seu objeto especial. Ora, este objeto especial não é de modo nenhum arbitrário, mas trata-se de uma relação social fundamental até hoje pouco tematizada como tal: mesmo que as mulheres foram e são consideradas a priori como "peculiares, menores, diferentes" (Gudrun-Axeli Knapp), inclusive na maioria das outras culturas e regiões do mundo, e justamente por essa

\section{gengrafaress}

Revista do Programa de Pós-Graduação em Geografia e do Departamento de Geografia da UFES

Janeiro-Junho, 2019 ISSN 2175-3709 


\section{Gentrafaress}

Revista do Programa de Pós-Graduação em Geografia e do Departamento de Geografia da UFES

Janeiro-Junho, 2019 ISSN 2175-3709 razão a dissociação do feminino como princípio fundamental foi dissimulada também na teoria e na ciência, nem por isso a teoria fundamental do valor-dissociação deve ser formalizada como simples auto-relativização, e tampouco o gênero pode ser concebido como apenas uma diferença e hierarquia entre muitas diferenças e hierarquias (cf. Scholz, 2011).

$\mathrm{Na}$ guerra civil mundial, resultante do valor-dissociação considerado em toda a sua complexidade como contexto fetichista basilar, também as mulheres se tornam relevantes como administradoras da crise, seja na forma de grupos de auto-ajuda existentes na periferia, seja na forma de relações sociológicas de desigualdade nas estruturas do poder - inclusive à escala global - independentemente de "raça", classe e gênero, justamente quando o patriarcado capitalista está sem conserto e nada se pode conseguir à maneira patriarcal habitual. Mas as mulheres também retornam aqui à situação de maltratadas com a máxima "trivialidade", forçadas à prostituição, ao emprego doméstico etc. (em sua grande maioria, migrantes). Nesse sentido, o aumento parcial do poder das mulheres se configura como uma vitória de Pirro que reside no horizonte de queda do patriarcado capitalista em colapso, e que, portanto, tem muito pouco a ver com emancipação, no sentido de uma suplantação fundamental de tais relações.

A teoria do valor-dissociação, como já foi dito, deve reformular a contradição em pro- cesso desta maneira. Ou seja, não é simplesmente o valor (a mais-valia) que produz a dinâmica impulsionada pela contradição, mas a dissociação é o seu próprio pressuposto em cruzamento dialético, entroncamento que possibilita tal dinâmica e apenas assim engendra o "sujeito automático". Por conseguinte, é o valor-dissociação, como princípio dinâmico do patriarcado capitalista, que também se modifica a si mesmo neste processo contraditório e determina todo o desenvolvimento histórico e o "movimento em si mesmo" através de todas as etapas históricas até o atual asselvajamento do patriarcado.

Aqui é preciso acentuar e reter mais uma vez o seguinte: é fato que não podemos partir de um patriarcado universal a priori, sequer em tempos pré-modernos ou noutras culturas, pois quanto a isto não apenas houveram muitas exceções nas sociedades não-modernas (cf. Arbeitsgruppe Ethnologie Wien, 1989) como também se faz necessário distinguir as diversas faces das hierarquias patriarcais. Por outro lado, também não podemos ignorar que desde os tempos pré-modernos até hoje a maioria das sociedades foram/são patriarcalmente constituídas. As concepções desconstrutivistas, que partem sempre de inter-relações de gênero, já não conseguem ter em conta este fato, pois para tais concepções este dado violento simplesmente desaparece como num passe de mágica. Também não se trata de cair num ponto de vista absolutamente relativista e historicista da cultura e 
nem de promover a hipostasia da diferença, como era usual nas abordagens pós-modernas das últimas décadas. Do mesmo modo é preciso assumir que as concepções de gênero bem como os modos de vida ocidentais formaram diferentes amálgamas com as estruturas patriarcais tradicionais, inclusive na periferia. A afirmação do valor-dissociação como contexto social basilar, considerado num alto grau de abstração, não deve aqui ser confundida com um ponto de vista ocidental de classe média que generaliza a posição das mulheres que dela fazem parte; pelo contrário, trata-se aqui de uma estrutura objetiva fundamental que não se confunde com determinações identitárias, pontos de vista e interesses particulares. Neste caso é preciso considerar que o modelo civilizacional patriarcal ocidental de fato aspira a submeter tudo até o seu desmoronamento, o que significa reconhecer à escala mundial uma totalidade social fragmentária no sentido do valor-dissociação. Federici não consegue pensar um tal plano fundamental porque raciocina de forma identitária a priori, na base do marxismo do movimento operário operaísta, e nesse sentido considera as mulheres, os camponeses, os povos indígenas, os trabalhadores migrantes pós-proletários como oprimidos e “colonizados pelo capital”. Sem universalizar o valor-dissociação de uma maneira equivocada, é preciso hoje entender muito bem, no sentido da crítica do valor-dissociação, as dimensões de "raça", classe, gênero e colo- nização [Kolonialisierung] nas diferentes regiões do mundo, assim como as desigualdades, os processos relativos à globalização e o desmoronamento do patriarcado capitalista num cenário de guerra civil mundial, no contexto de uma "contradição em processo" transformada.

Nesse sentido, o atributo "feminino" também não pode ser considerado de maneira utópica uma vez que é imanente ao contexto da socialização fragmentária do valor-dissociação, como o Outro do valor. Neste contexto seria preciso igualmente criticar as chamadas relações heteronormativas que, como arranjo heterossexual nas sociedades modernas, advém da divisão dos domínios da produção e da reprodução, sem desconsiderar que as relações de gênero majoritárias presentes nas sociedades tradicionais não raramente implicavam uma hierarquia de gênero entre homens e mulheres, circunstância amiúde obscurecida na argumentação pós-moderna. A questão sobre a dupla sexualidade não significa, de modo nenhum, uma garantia de que a hierarquia entre homem e mulher desapareça. Tanto quanto as diferentes dimensões também tenham de ser levadas em conta, o valor-dissociação, como contexto categorial basilar, não pode ser simplesmente extrapolado e diferenciado. Como metateoria abrangente, que reconhece sua própria limitação e nunca pode colocar-se ingenuamente como universalista, ela deve ser incondicionalmente afirmada como tal, pois é perante este

\section{gengrafaress}

Revista do Programa de Pós-Graduação em Geografia e do Departamento de Geografia da UFES

Janeiro-Junho, 2019 ISSN 2175-3709 


\section{Gentrafaress}

Revista do Programa de Pós-Graduação em Geografia e do Departamento de Geografia da UFES

Janeiro-Junho, 2019 ISSN 2175-3709 pano de fundo que as mudanças nas relações de gênero podem ser compreendidas. Em outras palavras, o valor-dissociação, como contexto basilar, tem de ser visto em certa medida como o verdadeiro fundamento social que co-constitui essencialmente o capital como sujeito automático, ou seja, o fetiche do capital, que por sua vez só se torna possível a partir dele. Desta maneira o valor-dissociação se desvencilha do ponto de vista do marxismo do movimento operário, que por sua vez também não pode ser transferido para outros sujeitos, como insiste Federici, e se descola de qualquer noção de uma contradição principal. Isso já é frustrado pelo seu objeto próprio, a contradição de gênero, uma vez que esta -,ceterum censeo,está condenada a arranjar realmente lugar sob aquilo que não lhe submete, de acordo com a sua própria lógica.

Dörre argumenta contra outras teorias da colonização surgidas no contexto femininista:

Com a violenta gestação de relações de exploração utilizadas no trabalho de subsistência, declara-se um mecanismo de formação inespecífica como sendo, no entanto, de validade geral e fundamental, o qual justamente não corresponde ao princípio capitalista da troca de equivalentes. A exploração, na sua versão essencial a montante da produção de mais-valia, é considerada como logro baseado na força, como "roubo". Pelo contrário a teoria de Marx pretende esclarecer como é possível a exploração, apesar do princípio da igualdade contratual vigente no mercado de trabalho (Dörre, 2015, p 45 - grifo do autor).

No que diz respeito às últimas, Dörre fala de "formas de exploração primárias", enquanto qualifica as primeiras como "formas de exploração secundárias".

Pode-se então falar de exploração secundária sempre que são utilizados mecanis- mos de disciplinamento legitimados em termos simbólico-culturais, políticos ou estatais, com o objetivo de conservar diferenças entre o que está dentro e aquilo que se encontra fora, a fim de pressionar a força de trabalho ou o nível de vida de grupos sociais através da desvalorização racista ou sexista, por exemplo, claramente abaixo do nível salarial geral e da reprodução assegurada pelo Estado de bem-estar social, ou ainda, a fim de poder utilizar atividades dentro e fora da esfera profissional como recursos grátis não-pagos" (Dörre, 2015, p. 46).

Aqui encontramos a velha tese da contradição principal e secundária apresentada por Dörre em novo design colonial. "Forma" para ele é apenas a antiga "forma" mediada pela mais-valia. Ele não alcança a determinação do valor-dissociação, como contexto basilar contraditório e em processo, ou seja, uma relação de valor-dissociação que sabe do sem-forma (dissociado) em mediação dialética com o valor (mais-valia) como seu pressuposto não reconhecido, o que também implica que os diferentes planos, dimensões e domínios no interior da teoria do valor-dissociação têm de ser tidos em conta em sua lógica própria. "Dissociação" é assim de certa maneira um conceito-anticonceito e apenas ele possibilita um conceito da forma capitalista do valor (da mais-valia) em geral. Dörre está muito longe de tais ideias, como também Federici. Particularmente Dörre talvez devesse "trabalhar" um pouco mais as suas ideias (androcêntricas) de forma. As atividades femininas relativas ao cuidado deveriam assim representar designadamente o "Outro", mas onde está a determinação de que a dimensão sexual é realmente o decisivo, o constituinte da forma? É preciso tê-lo em conta, mesmo se esta dimensão 
do valor-dissociação - como se viu - deva depois igualmente se retirar, considerando Outros com "iguais" direitos.

\section{Teorias da colonização e per- spectivas de transformação}

Conforme foi referido, para Dörre, as intervenções estatais, não em último lugar promovidas pelos movimentos sociais de protesto, são cruciais para efetuar uma mudança social fundamental. Assim, talvez, poderiam materializar um novo "Green New Deal" e um novo "ciclo Kondratiev" ecológico. Para ele, o objetivo é sobretudo uma dimensão de pós-crescimento acoplada a uma perspectiva de redistribuição. Correspondentemente, as instituições "trabalho profissional, constituição econômica, [...], Estado de bem-estar e democracia" têm de ser modificadas (Dörre, 2013, p. 135).

No fundo, lamenta-se pelo fim do socialismo real, o qual possuíra uma perspectiva de propriedade coletiva que agora se pretende reinstalar: "O campo de intervenções ecológicas e inovações verdes decisivas é descoberto como acumulador potencial, que deverá possibilitar tanto o crescimento de longo prazo como também a sua descarbonização e desmaterialização" (Dörre, 2013, p. 136). Isto teria agora de acontecer no contexto de uma "ordem mundial multilateral", uma perspectiva que de resto permanece em grande parte exterior à análise de Dörre (Dörre, 2015, p. 599).

Dörre vê aqui perfeitamente que mesmo as "melhores concepções de Green New Deal" não apresentam no fundo qualquer solução para o dilema do crescimento. E constata: "A transição para sociedades pós-crescimento apresenta-se atualmente como utópica, pois isso afeta o núcleo essencial da socialização capitalista" (Dörre, 2013, p. 136). "Núcleo essencial" quer dizer orientação para o lucro e crescimento compulsivo, no fundo entendidos no contexto de uma velha relação de classes. Apesar de todo o ceticismo, em Dörre se pode reconhecer que continua presente de algum modo uma perspectiva socialdemocrata. Ainda que as esperanças socialdemocratas tenham se envergonhado até à medula com os exemplos de Obama e Tsipras.

Neste contexto vago, ele também vê presentemente embriões para uma transformação social. Reconhece "nas atividades de alimentar, educar, formar, cuidar e proteger", hoje mal pagas e dificilmente suscetíveis de racionalização, que são executadas sobretudo por mulheres,

os setores que conseguem crescer - lentamente - no capitalismo avançado. Valorização e melhor pagamento de uma parte destas atividades, financiamento através de impostos e política redistributiva, novas formas de propriedade, como prestação de serviços organizada cooperativamente, democratização do trabalho de prestação de serviços através da cogestão de produtores e clientes, reduções de horário de trabalho justas em termos de gênero e tempo para a democracia, estas são algumas importantes notas para uma perspectiva de transformação centrada no trabalho com sentido. Tal transformação não se consegue sem o controle público de setores sociais chave (energia, finanças, etc.). Ela teria de transformar as grandes empresas com posição dominante no mercado naquilo que elas implicitamente já são - instituições públicas, cujas atividades estão ligadas a uma vontade coletiva democrática (Dör-

\section{GenGrafaress}

Revista do Programa de Pós-Graduação em Geografia e do Departamento de Geografia da UFES

Janeiro-Junho, 2019 ISSN 2175-3709 


\section{GenGrafaress}

Revista do Programa de Pós-Graduação em Geografia e do Departamento de Geografia da UFES

Janeiro-Junho, 2019 ISSN 2175-3709 re, 2013, p. 138)

Aqui se torna claro em Dörre o vivo interesse em manter um capitalismo (domesticado) e não só. No caso das "melhores concepções de Green New Deal", a questão não é apenas se com as suas exigências seria possível parar a espiral de crescimento no capitalismo, mas também como podem um Green New Deal, tal como os trabalhos (femininos) de cuidado, serem apoiados em tempos de financeirização, de circuitos de déficit e da obsolescência do trabalho abstrato, que já não admitem mecanismos de compensação como no fordismo, quando hoje em toda a parte vem à luz do dia uma contradição entre matéria e forma, acompanhada por uma diminuição da massa de mais-valia (cf. também Ortlieb, 2009).

Isto significa, concretamente, que o Estado também dispõe de menos impostos para financiar as atividades de reprodução. Assim, levanta-se a questão de saber porque haveria o capital de investir justamente em tais domínios não rentáveis, se uma aplicação nos mercados financeiros é essencialmente mais lucrativa. Além disso, Dörre coloca o "gênero" como exterior à determinação da forma, por um lado, e, por outro lado, considera-o, justamente por isso, como transcendente (trabalhos de cuidar). Trata-se simplesmente de um modo superficial de ver, o que na realidade é, por assim dizer, uma lei imanente ao patriarcado que as mulheres e o que lhes está associado sejam vistas como solução e saída para a miséria capitalista, de acordo com um cântico religioso católico: "Estende o teu manto, Maria!" (cf. Scholz, 2009b). Em vez disso, a dissociação-valor deveria de ser colocada como relação social basilar, na sua contraditoriedade processual, em que o feminino terá de ser visto como a forma sem forma da forma do valor, como pressuposto para que o valor (mais-valia) possa existir em geral. Que, todavia, é posto como o "Um".

Dörre também inclui no seu portfólio de transformação algo como uma "economia solidária". Aqui as atividades femininas de reprodução são somente uma entre muitas formas de atividades informais. "É necessário testar alternativas práticas, reconstruindo setores eliminados pelo setor privado - como a economia solidária ou o setor público" (Dörre, 2015, p. 602). Longe de quaisquer ideias de crítica do fetichismo, mais uma vez se hipostasia assim imediatamente um plano prático na forma de pseudoconcepções.

Aqui ele se encontra mais uma vez com Federici, que vê nos "comuns" e na "economia solidária" uma saída do capitalismo:

Nos EUA observamos também o desenvolvimento de diferentes "economias solidárias", que consistem em bancos de tempo, moedas locais, conhecimento comum (knowledge commons), troca direta e diversas outras formas de autossubsistência comunitária e apoio recíproco $(\mathrm{Fe}$ derici, 2013, p. 50 e ss - grifo da autora).

Aqui se torna visível que o fundamento da proposição, no fundo, está completamente presa a critérios, categorias e quantidades imanentes, em que se trata de compensar algo: bancos de tempo, moedas locais, propriedade jurídica e respectiva 
democratização etc., "enquanto o verdadeiro problema da suplantação da forma da mercadoria permanece escondido" (Kurz, 2013b, p. 137 e ss.).

O pressuposto aqui seria naturalmente partir de uma teoria da relação do valor-dissociação em processo, a qual, para se afirmar a si mesma, tem simultaneamente de se distanciar de si mesma e, neste contexto, não apenas incluir dimensões aparentemente qualitativas como a ecologia, mas também desigualdades sociais como "raça", classe, gênero, antissemitismo e anticiganismo, para além do velho esquema das classes.

A partir daqui também seria preciso questionar (ver acima) pseudoconcepções imediatas à la "comuns", economia solidária e esquemas de open-source, que se apresentam todas como possibilidades de solução no contexto de uma crítica do valor popular, atualmente com muita saída. Sem embargo, de resto, as discussões sobre indústria 4.0 e capitalismo 4.0 no contexto da cena dos "comuns" e do open-source desempenhariam um papel (impressoras 3D, ligação em rede de máquinas e produtores/as, Big Data etc.): se a robotização de "todos e cada um" no discurso hegemônico é muitas vezes pressentida como chance para a sobrevivência do capitalismo, os respectivos desenvolvimentos, por outro lado, são muitas vezes tratados - numa perspectiva rasteira $\mathrm{e}$ limitada - como possibilidade para esboçar novas utopias. Em vez disso seria possível tratar, com uma visão crítica, de sondar estas novas potencialidades tecnológicas, tendo por fundo justamente a crítica do valor-dissociação, sob os pontos de vista da ecologia social - como tão bem se lhes chama sempre - para uma mudança sistêmica radical abrangente, pontos de vista que não se percam numa ideologia do pequeno, baseada numa filosofia vitalista, à qual, como se viu, não em último lugar também as perspectivas de colonização se submetem.

Entretanto, trata-se de tudo menos da dissociação do feminino, que constitui o pressuposto dialético do trabalho abstrato. Em vez disso, a perspectiva da dissociação é muitas vezes incluída apenas como apêndice do valor, ou referida como questão secundária. Claro que não é percebido o carácter dialético negativo do valor-dissociação, nem do seu entendimento da totalidade, ela que já se entendeu sempre como em si fragmentária juntamente com a sua determinação do racismo, antissemitismo, anticiganismo e disparidades econômicas à escala mundial do processo histórico, incluindo uma crítica da história do colonialismo.

A velha crítica do valor androcêntrica e universalista tem de ser mantida de modo obviamente desesperado e continua a se afirmar como tal. Como se a forma fundamental do valor-dissociação nunca tivesse sido formulada, ou existido. Assim como, por exemplo, na Never Work Conference (uma conferência de crítica do valor ocorrida na Inglaterra, em que críticos do trabalho universalistas e androcêntricos ficaram entre si, tendo o valor-dissociação como

\section{gengrafaress}

Revista do Programa de Pós-Graduação em Geografia e do Departamento de Geografia da UFES

Janeiro-Junho, 2019 ISSN 2175-3709 


\section{GEOGRAFARES}

Revista do Programa de Pós-Graduação em Geografia e do Departamento de Geografia da UFES

Janeiro-Junho, 2019

ISSN 2175-3709 contexto social basilar sido te- reificação - "Viva o fetiche!" matizado quando muito de passagem, com ampla exclusão das mulheres), que prestou-se a que a perspectiva do "Terceiro Mundo" parecesse, com certeza, incluída. O fetiche abstrato do trabalho em toda a sua
- festeja-se, enquanto ele aparentemente se nega a si mesmo (Scholz, 2014). Tudo isto, claro, na discussão acadêmica (masculina) internacional, atravessando contextos e países. 


\section{NOTAS}

1 - Agradecemos enormemente à autorização dada pessoalmente pela autora para essa revisão da tradução e para a sua publicação.

Texto original: SCHOLZ, R. Christoph Kolumbus Forever? Zur Kritik heutiger Landnahme-Theorien vor dem Hintergrund des „Kollaps der Modernisierung“. Exit! Krise und Kritik der Warengesellschaft, n. 13, Horlemann Verlag, Deutschland, jan., 2016, pp. 46-100.

2 - Agradecemos enormemente à autorização dada pessoalmente pelo tradutor para essa revisão para o português do Brasil e para a sua publicação.

Tradução base: SCHOLZ, R. Cristóvão Colombo Forever? Para a crítica das actuais teorias da colonização no contexto do "Colapso da modernização". ANTUNES, B. (trad.). Disponível em: http:// www.obeco-online.org/roswitha scholz24.htm. Acesso em: 07/02/2019.

3 - Como o leitor poderá conferir o conceito de colonização tem proeminência no texto de Roswitha Scholz, ainda que esteja referida a duas palavras distintas no original alemão: "Landnahme", e "Kolonialisierung". Mais frequentemente colonização está traduzindo o conceito de "Landnahme", cunhado por Dörre, já nas situações em que o conceito em alemão é outro, o exibimos entre colchetes. Faz-se necessário mencionar que o conceito de colonização busca dar conta de distintos contextos: o primeiro deles diz respeito ao conceito de acumulação original (ou primitiva), bem como da moderna colonização, ambos contextos apresentados por Karl Marx n'O Capital; o segundo se refere ao debate ocorrido na segunda internacional, sintetizada por Rosa Luxemburgo em seu A acumulação do capital, no qual a autora questiona se a acumulação primitiva se restringiria ao contexto histórico de formação do capitalismo como apresentado por Marx; o terceiro emergiu predominantemente no debate latino-americano ao tentar dar conta do processo de expansão do capital e suplantação de relações não-tipicamente capitalistas (a chamada questão agrária); e o quarto, e último, se refere ao debate contemporâneo sobre a possibilidade da expansão do capital funcionar como uma solução, mesmo que provisória, para as crises do capitalismo. Esse último debate está presente, por exemplo, nos conceitos de acumulação por espoliação apresentado por Harvey em seu livro $\mathrm{O}$ novo imperialismo (2003), ou mesmo no de expulsão apresentada pelo livro Expulsões de Saskia Sassen (2016), e na ideia mais geral de land-grabbing, com várias conceituações possíveis. [Nota dos revisores para esse Dossiê - a partir daqui NR]

4 - Certamente se poderia colocar em questão se a inovação das armas de fogo foi essencialmente constitutiva do capitalismo, mas há um consenso generalizado que reconhece na obtenção de dinheiro para a guerra o objetivo supremo das fases absolutista e mercantilista.

\section{gentrafaress}

Revista do Programa de Pós-Graduação em Geografia e do Departamento de Geografia da UFES

Janeiro-Junho, 2019 ISSN 2175-3709 


\section{GenGrafaress}

Revista do Programa de Pós-Graduação em Geografia e do Departamento de Geografia da UFES

Janeiro-Junho, 2019 ISSN 2175-3709
5 - Na edição $n^{\circ} 14$ da revista EXIT! Krise und Kritik der Warengesellschaft, Richard Aabromeit também discute detalhadamente o papel do dinheiro e as teorias monetárias recentes (N. E.).

6 - Decisivo para a determinação da taxa de lucro, no entanto, é que ela não deve ser relacionada com o capital individual, mas com o capital global que não é economicamente mensurável e tampouco quantitativamente verificável, como pensam marxistas de diversos matizes e entre eles também Dörre (ver abaixo), e como também nos querem convencer modelos matemáticos da economia política amplamente divulgados (cf. Kurz, 2014, p. 277 e ss.). De acordo com isso também é absurda a hipótese de uma mercadoria do mercado financeiro, como mercadoria de segunda ordem, que teria salvado o capitalismo nas últimas décadas (cf. Lohoff, Trenkle 2012). Pelo contrário, o que aqui se mostra é o moderno patriarcado produtor de mercadorias tornando-se obsoleto como processo histórico no seu conjunto, o que não pode ser reduzido a uma ideia mecânica de um colapso repentino (ver acima); numa formulação mais complexa, a socialização patriarcal capitalista na forma da mercadoria não pode ser equiparada com a "propriedade", que agora deveria ser transferida para um estado quase natural nas formas dos commons. Pelo contrário, é preciso suplantá-la.

7 - Para essa adaptação, nas quais citamos a tradução brasileira realizada por Carolina Alves Vestena e Iasmin Goes do texto de autoria do próprio Dörre, adotamos a opção das mesmas pela manutenção do termo original alemão "Landnahme" que, por sua vez, aderiram à decisão dos tradutores do referido artigo para o inglês, que justificam assim a escolha: "Traduzido literalmente, Landnahme significa apropriação de terras (land grabbing), tomada da terra ou ganho territorial. Refere-se tanto à expansão capitalista interna como à externa. $\mathrm{O}$ conceito de Landnahme sustenta que as sociedades capitalistas não podem se reproduzir sobre seus próprios fundamentos a longo prazo. Para se reproduzirem, elas têm de ocupar continuamente e mercantilizar um "outro" não capitalista (p. ex., regiões, arredores, grupos e atividades). Trata-se, por assim dizer, de uma incessante repetição do ato de acumulação primitiva. Devido à dificuldade de encontrar uma tradução conclusiva exata, o termo Landnahme será utilizado ao longo do texto"" (cf. Dörre, Lessenich e Rosa, 2015).

8 - Kurz questiona o conceito de "divisão internacional do trabalho" no contexto dos atuais processos da globalização: “... nem sequer no sentido negativo da troca de mercadorias entre países industrialmente desenvolvidos se poderia falar de 'divisão de trabalho', no sentido que lhe dá Ricardo, cujo pressuposto seria que cada país se especializaria em determinados produtos ou componentes industriais de produção" (Kurz, 2005, p. 73). Mas não é esse o caso. Tal divisão do trabalho "só seria possível se se 
tratasse de uma associação, o mais racional possível, da produção mundial de bens naturais e materiais visando a satisfação das necessidades gerais. Mas o objetivo da produção capitalista é completamente diferente, a saber, o fim em si mesmo da valorização do capital" (Kurz, 2005, p. 74). Sendo isto, no entanto, dito apenas de passagem.

9 - Foram "as de Bielefeld" que primeiro formularam a teoria da colonização na "Nova Esquerda". Para elas, trata-se de mostrar "que a divisão hierárquica do trabalho entre os sexos, a submissão e exploração das mulheres representa a base e o fecho de todas as relações de exploração posteriores e que a colonização do mundo, a exploração da natureza, dos territórios e das pessoas, que o capitalismo mais que tudo precisa como pressuposto, seguem este padrão (...). O controle sobre as mulheres e sobre a terra é, portanto, o fundamento de todo o sistema baseado na exploração. Trata-se, assim, de possuir estas 'relações de produção'. A relação com elas é uma relação de apropriação. Esta relação de apropriação é, por um lado, o pressuposto para a formação da relação de produção central entre trabalho assalariado e capital, por outro lado, este último exige a apropriação das mulheres e das colónias como 'recursos naturais"” (von Werlhof/Bennholdt-Thomsen/Mies, 1983, p. 9 - grifo da autora). Escrevem elas ainda: "O mais importante conhecimento que se impôs com estudos mais detalhados das causas históricas da dominação masculina foi que sexismo e patriarcalismo não são sinais de atraso, mas sim componentes necessários, centralmente ideológicos e institucionais do sistema industrial e do seu modelo de acumulação" (von Werlhof/Bennholdt-Thomsen/Mies, 1983, p. 5). Von Werlhof e outras continuam Rosa Luxemburgo. Não podemos abordar aqui as diferenças entre "as de Bielefeld" e a concepção de Federici.

10 - Escreve ela neste contexto: "A apropriação pelo Estado dos corpos das mulheres e da sua capacidade de reprodução foi [...] o princípio da regulação dos recursos 'humanos', a primeira intervenção 'biopolítica' do Estado e a sua contribuição para a acumulação de capital, ao contribuir para o aumento do proletariado" (Priester, 2008, p. 43). É preciso pôr em dúvida que o "Estado" tenha feito um cálculo tendo em vista o "aumento do proletariado". Deixando de lado, por um instante, que o Estado em sentido moderno apenas começava a se constituir, o que aqui novamente vem em primeiro lugar é o ponto de vista marxista das classes de Federici. Também não deixa de ser questionável se as mulheres teriam sido de fato perseguidas como bruxas por causa do seu conhecimento sobre a contracepção, ou se não estaria aqui o desejo do pai do pensamento presente em determinadas correntes feministas (ver, por exemplo, Heinemann, 1989). Em todo o caso, o livro de Silvia Federici, "Calibã e a bruxa - mulheres, corpo e acumulação primitiva", no qual ela aborda a importância da caça às bruxas na formação do capitalismo, é no seu conjunto

\section{Gengrafaress}

Revista do Programa de Pós-Graduação em Geografia e do Departamento de Geografia da UFES

Janeiro-Junho, 2019

ISSN 2175-3709 


\section{GenGrafaress}

Revista do Programa de Pós-Graduação em Geografia e do Departamento de Geografia da UFES

Janeiro-Junho, 2019 ISSN 2175-3709 muito interessante pela revisão historiográfica (cf., por exemplo, Bareuther, 2014). Nesse sentido, uma crítica da dissociação-valor também poderá recorrer a este livro em vários aspectos, sem desconsiderar que o seu enquadramento operaísta é altamente problemático (cf. Federici, 2012b).

\section{1 - Equivalente (N.T.)}

12 - Para uma crítica da perspectiva que pressupõe que o processo de expansão do capital se deu sobre relações não-capitalistas, ou mesmo de estrita subsistência, nos países da periferia, ver os trabalhos de Leite (2015), Toledo (2008), Kluck (2017) e Boechat (2014), onde está discutido o complexo processo de territorialização do capital colonial (N.T.).

13 - Tais formulações, frequentemente surgidas em citações de Kurz no contexto aqui tratado, talvez já não fossem mais formuladas por ele nestes termos hoje, pois corresponderiam ao plano do capital individual e, portanto, baseadas no individualismo metodológico, ao invés disso Kurz apresentou a necessidade de considerar primeiramente o "movimento em si" do capital em sua totalidade (cf. Kurz, 2014). O que, sem embargo, não constitui uma ruptura em sua argumentação, visto que para ele sempre esteve em questão a totalidade do capital, mesmo que ainda estivesse preso a um vocabulário ligado ao capital individual-particular que não corresponde verdadeiramente ao conteúdo do primeiro.

14 - "O fraturamento hidráulico, também conhecido como fracking, é utilizado para realizar perfurações para a extração de gás de xisto ou gás de folhelho (em inglês, é chamado de shale gas)". (fonte: http://naofrackingbrasil.com.br/o-que-e-fracking/ - Acesso: $20 \mathrm{de}$ fev. 2019). (NT)

15-Gramscie Althusser, por exemplo, muito dificilmentenão seriam enquadrados no marxismo do movimento operário, ao contrário, porventura, da Escola de Frankfurt até Backhaus e Cia. Ingo Elbe, se valendo do conceito geral de "marxismo ocidental", aplica a mesma bitola a situações diferentes. Marxismos centralmente críticos do fetichismo da mercadoria são equiparados a marxismos estruturalistas e politicistas, ainda profundamente vinculados ao marxismo tradicional (como é o caso em Elbe 2008). Seria preciso ainda diferenciar a crítica do valor-dissociação, que vai além de ambas perspectivas. Tal perspectiva, no entanto, é posta de lado por Elbe, porque trata única e exclusivamente dos marxismos ocidentais androcêntricos. Todas as outras tendências do marxismo, como por exemplo aquelas de proveniência pós-colonial (mesmo baseadas em Gramsci e Althusser) ficam excluídas de sua análise.

16 - A Alemanha Biedermeier de Merkel, apesar de Hartz IV e outras coisas, considera-se longe disso sem razão, segundo a divisa: "Bom São Floriano, poupai a minha casa, queimai as outras". O que acontece quando a falsa segurança se revela como tal (o que no fundo todos sabem) não precisa realmente aqui de 
mais explicações. Na Alemanha, a pobreza aumenta cada vez mais, como é geralmente conhecido; com referência à Grécia, ocorre aqui apenas uma externalização dos custos internos, mesmo ideais. O ressentimento contra judeus, "ciganos" e outros "estrangeiros" nas últimas décadas "pós-modernas" já fala aqui uma linguagem eloquente. Apesar de toda a pseudo-revisão do nacional-socialismo e do Holocausto nos últimos anos, já se diz agora oficialmente "Tu és Alemanha". Deus nos livre (e, sobretudo, "aos outros") se, com a continuação do desenvolvimento social, a coisa ainda se agrava mais. Também os incêndios de casas de requerentes de asilo tiveram a meio da década de 2010 novamente uma conjuntura em alta. E ainda vêm aí mais refugiados.

*O período Biedermeier (1815-1848) está associado à restauração alemã e é marcado pelo conservadorismo na política, na literatura e na arte (N. T).

17 - Sobre isso, ver observações de Gerd Bedszent relativamente à Nigéria na Revista EXIT! n 13.

ADORNO, T. W. Negative Dialektik. Frankfurt am Main, 1966 [ed. bras.: Dialética negativa, trad. Marco Antonio Casanova, São Paulo, Zahar, 2009]. 


\section{GenGrafaress}

Revista do Programa de Pós-Graduação em Geografia e do Departamento de Geografia da UFES

Janeiro-Junho, 2019 ISSN 2175-3709

\section{REFERÊNCIAS BIBLIOGRÁFICAS}

ARBEITSGRUPPE ETHNOLOGIE WIEN (Hrgs.). Von fremden Frauen [Das mulheres estrangeiras], Frankfurt am Main, 1989.

BAREUTHER, Johannes. Zum Androzentrismus der naturbeherrschenden Vernunft (Teil 1) Dämonische und mechanische Natur. EXIT! Krise und Kritik der Warengesellschaft, n. 12, nov., 2014, p. 18-52 [ed. port.: O androcentrismo da razão dominadora da natureza ( $1^{\mathrm{a}}$ parte) Natureza demoníaca e natureza mecânica, trad. Boaventura Antunes, 2015. Disponível em: http://www.obeco-online.org/johannes_bareuther1.htm. Acesso em: 07/02/2019].

BEDSZENT, G. Zusammenbruch der Peripherie. Gescheiterte Staaten als Tummelplatz von Drogenbaronen, Warlords und Weltordnungskriegern [Colapso da periferia. Estados falidos como campo de jogos de barões da droga, senhores da guerra e guerreiros do ordenamento mundial], Berlin, 2014.

DEMIROVIC, A.; DÜCK, J.; BECKER, F.; BADER, P. (Hrsg.). Vielfachkrise. Im finanzmarktdominierten Kapitalismus [Crise múltipla. No capitalismo dominado pelo mercado financeiro], Hamburg, 2011.

DÖRRE, K. A nova Landnahme. Dinâmicas e limites do capitalismo financeiro. Revista Direito e Práxis, Rio de Janeiro, v. 6, n. 12, 2015, p. 536-603.

DÖRRE, K. Landnahme, Triebkräfte, Wirkungen und Grenzen kapitalistischer Wachstumsdynamik [Colonização, forças propulsoras, efeitos e limites da dinâmica de crescimento capitalista]. BACKHOUES, M.; GERLACH, O.; NOWK, A. (Hrsg.). Die globale Einhegung - Krise, ursprüngliche Akkumulation und Landnahmen im Kapitalismus [A cerca global - Crise, acumulação primitiva e colonizações no capitalismo], Münster, 2013, p. 112-140.

DÖRRE, K. Marxsche Theorie und kritische Soziologie: Acht Thesen zu einer Wahlverwandtschaft [Teoria de Marx e sociologia crítica. Oito teses para uma afinidade eleitoral]. DEMIROVIC, A.; KLAUKE, S.; SCHNEIDER, E. Was ist der „Stand des Marxismus"? Soziale und epistemologische Bedingungen der kritischen Theorie heute [Qual é o "estado do marxismo"? Condições sociais e epistemológicas da teoria crítica hoje], Berlin, 2015.

ELBE, I. Marx im Westen. Die neue Marxlektüre in der Bundesrepublik seit 1965 [Marx no Ocidente. A Nova Leitura de Marx na República Federal desde 1965], Berlin, 2008.

FEDERICI, S. Die Reproduktion der Arbeitskraft im globalen 
Kapitalismus und die unvollendete Revolution [A reprodução da força de trabalho no capitalismo global e a revolução inacabada]. FEDERICI, S. Aufstand aus der Küche Reproduktionsarbeit im globalen Kapitalismus und die unvollendete feministische Revolution [A revolta a partir do trabalho de reprodução na cozinha no capitalismo global e a revolução feminista inacabada], Münster, 2012, p. 21-86.

FEDERICI, S. Calibã e a Bruxa. Mulheres, corpo e acumulação primitiva, trad. Coletivo Sycorax. $1^{\mathrm{a}}$ edição. São Paulo: Elefante Editora, 2017.

FEDERICI, S. Ursprüngliche Akkumulation, Globalisierung und Reproduktion [Acumulação primitiva, globalização e reprodução]. BACKHOUSE, M.; GERLACH, O.; NOWAK, A. (HRSG.). Die globale Einhegung-Krise, ursprüngliche Akkumulation und Landnahmen im Kapitalismus [A crise da cerca global, acumulação primitiva e colonização no capitalismo], Münster, 2013, p. 40-52.

FEMINISTICHE AUTORINNENGRUPPE. Das Theorem der neuen Landnahme: Eine feministische Rückeroberung [O teorema da nova colonização. Uma reconquista feminista]. BAUMANN, H.; BISCHEL, I.; GEMPERLE, M.; RINGER, B.; SCHATZ, H. (Hrsg.). Denknetz Jahrbuch. Züriich, 2013, p. 99-116.

HEINEMANN, E. Hexen und Hexenangst. Eine psychoanalytische Studie des Hexenwahns der frühen Neuzeit [Bruxas e medo das bruxas. Um estudo psicanalítico da mania das bruxas no início da Idade Moderna]. Frankfurt a. Main, 1989.

KONICZ, Tomasz. Droht China ein Kollaps? Dem schuldenfinanzierten Wachstum der chinesischen Wirtschaft geht die Puste aus. Erhältlich in: www.exit-online.org/link.php?tabelle=autoren\&posnr=540. Zugang in: 07/02/2019. [ed. port.: Estará a china na iminência de um colapso? $\mathrm{O}$ crescimento da economia chinesa financiado pelo endividamento não aguenta mais, trad. Boaventura Antunes. Disponível em: www.obeco-online.org/tomasz_konicz4.htm. Acesso em: 07/02/2019.

KURZ, R. Die Krise des Tauschwerts. Produktivkraft Wissenschaft, produktive Arbeit und kapitalistische Reproduktion. Marxistische Kritik, v. 1, Krise der Arbeit - Arbeit der Krise [Crise do trabalho, trabalho da crise]. Nuremberg, 1987, p. 7-48. [ed. bras.: A crise do valor de troca, trad. André Villar Gomez e Marco Barreira, Rio de Janeiro, Editora Consequência, 2018].

KURZ, R. O colapso da modernização. Da derrocada do socialismo de caserna à crise da economia mundial, $2^{\mathrm{a}}$ edição, trad.

\section{GenGrafaress}

Revista do Programa de Pós-Graduação em Geografia e do Departamento de Geografia da UFES

Janeiro-Junho, 2019

ISSN 2175-3709 


\section{GEOGRAFARESS}

Revista do Programa de Pós-Graduação em Geografia e do Departamento de Geografia da UFES

Janeiro-Junho, 2019 ISSN 2175-3709
Karen Elsabe Barbosa. São Paulo: Editora Paz e Terra, 1993.

KURZ, R. Das Weltkartenhaus. Globalisierung der Märkte und fiktives Kapital [O castelo de cartas mundial. Globalização dos mercados e capital fictício]. Lettre International, 1994, n. 27, p. 93-94.

KURZ, R. Weltordnungskrieg. Das Ende der Souveränität und die Wandlungen des Imperialismus im Zeitalter der Globalisierung, Bad Honnef, 2003. [ed. port. parcial.: A Guerra de Ordenamento Mundial. O Fim da Soberania e as Metamorfoses do Imperialismo na Era da Globalização, trad. Boaventura Antunes. Disponível em: www.obeco-online.org/livro_guerra_ordenamento.htm. Acesso em: 07/02/2019].

KURZ, R. Das Weltkapital. Globalisierung und innere Schranken des modernen warenproduzierenden Systems [O capital mundial. Globalização e limites internos do moderno sistema produtor de mercadorias], Berlin, 2005.

KURZ, R. Dinheiro sem valor. Linhas gerais para a transformação da crítica da economia política, trad. Lumir Nahodil. Lisboa: Editora Antígona, 2014.

KURZ, R. Die Klimax des Kapitalismus [O clímax do capitalismo]. KURZ, R. Weltkrise und Ignoranz. Kapitalismus im Niedergang [Crise mundial e ignorância. $\mathrm{O}$ capitalismo em declínio], Berlin: Edition Tiamat, 2013a, p. 229-238. [ed. port. O clímax do capitalismo. Breve esboço da dinâmica histórica da crise, trad. Boaventura Antunes. Disponível em: http://www.obeco-online. org/rkurz414.htm. Acesso em: 07/02/2019].

KURZ, R. Enteignung und Aneignung. Zur Debatte um das jüngste Zauberwort einer kurz greifenden Kapitalismuskritik. [Expropriação e apropriação. Para o debate sobre a última palavra mágica de uma crítica do capitalismo de curto alcance]. KURZ, R. Weltkrise und Ignoranz. Kapitalismus in Niedergang [Crise mundial e ignorância. O capitalismo em declínio], Berlin: Edition Tiamat, 2013b, p. 133-140.

NEVER WORK CONFERENCE, Cardiff. U. K., Available online: http://sites.cardiff.ac.uk/events/never-work-conference/. Access in: 06.07.2015. 10/7/2015.

LOHOFF, E.; TRENKLE, N. (GRUPPE KRISIS). Die große Entwertung: Warum Spekulation und Staatsverschuldung nicht die Ursache der Krise sind [A grande desvalorização. Porque a especulação e a dívida pública não são as causas da crise], Münster, 2012. 
ORTLIEB, C. P. Ein Widerspruch von Stof und Form. Zur Bedeutung der Produktion des relativen Mehrwerts für die fiale Krisendynamik. Nuremberg: Exit n. 6, Bad Honnef, 2009. [ed. port.: Uma contradição entre matéria e forma. Sobre a importância da produção de mais-valia relativa para a dinâmica de crise final, trad. Boaventura Antunes e Lumir Nahodil, 2010. Disponível em: http:// o-beco-pt.blogspot.com/2010/06/claus-peter-ortlieb-uma-contradicao.html. Acesso em: 07/02/2019].

POSTONE, M. Tempo, trabalho e dominação social. Uma reinterpretação da teoria crítica de Marx. $1^{a}$ edição, trad. Amilton Reis e Paulo Cézar Castanheira. São Paulo: Boitempo Editorial, 2014.

PRIESTER, Karin. Messianischer Populismus von links? Anmerkungen zu dem Werk EMPIRE von Michael Hardt und Antonio Negri [Populismo messiânico de esquerda? Notas sobre o livro EMPIRE de Michael Hardt e Antonio Negri]. EICKELPASH, R.; RADEMACHER, C.; RAMOS LOBATO, P. (Hrsg.). Metamorphosen des Kapitalismus und seiner Kritik [Metamorfoses do capitalismo e sua crítica], Wiesbaden, 2008, p. 48-59.

REDAKTION PROKLA. Call for Papers 179: Illusion und Macht des Geldes [Call for papers 179. A ilusão e o poder do dinheiro], 2015. Erhältlich in: http://www.prokla.de/2014/09/30/ cfp-179. Zugang in: 07/02/2019.

ROMMELSPACHER, B. Rassismus umd Sexismus in feministischen Diskurs [Racismo e sexismo no discurso feminista]. ROMMELSPACHER, B. Dominanzkultur: Texte zu Fremdheit und Macht [Cultura dominante: textos sobre alienação e poder], Berlin, 1995, p. 102-114.

SCHEICH, E. Naturbeherrschung und Weiblichkeit: Denkformen und Phantasmen der modernen Naturwissenschaften [Dominação a natureza e feminilidade. Formas de pensar e fantasmas das ciências naturais modernas]. Pfaffenweiler, 1993.

SCHOLZ, R. Der Wert ist der Mann. Thesen zu Wertvergesellschaftung und Geschlechterverhältnis. Krisis, n. 12, 1992. Erhältlich in: http://www.exit-online.org/linkgen.php?tabelle=autoren\&posnr=25. Zugang in: 07/02/2019 [ed. bras.: O valor é o homem. Teses sobre a socialização do valor e a relação entre os sexos. Disponível em: http://www.obeco-online.org/rst1.htm. Acesso em: 07/02/2019].

SCHOLZ, R. Differenzen der Krise - Krise der Differenzen. Die neue Gesellschaftskritik im globalen Zeitalter und der Zusammenhang von „Rasse”, Klasse, Geschlecht und postmoderner Individualisierung, Bad Honnef, 2005 [ed. port. Diferenças da

\section{GenGrafaress}

Revista do Programa de Pós-Graduação em Geografia e do Departamento de Geografia da UFES

Janeiro-Junho, 2019

ISSN 2175-3709 


\section{BEOGRAFARESS}

Revista do Programa de Pós-Graduação em Geografia e do Departamento de Geografia da UFES

Janeiro-Junho, 2019

ISSN 2175-3709 crise - Crise das diferenças. A nova crítica social na era global e a conexão de "raça", classe, sexo e individualização pós-moderna. Disponível em: http://obeco.no.sapo.pt/livro_crise_diferenca.htm. Acesso em: 07/02/2019].

SCHOLZ, R. Überflüssig Sein und „Mittelschichtsangst”. Das Phänomen der Exklusion und die soziale Stratifikation im Kapitalismus. EXIT! Krise und Kritik der Warengesellschaft, 5, 2008, p. 58-105 [ed. port.: O ser-se supérfluo e a "angústia da classe média". O fenómeno da exclusão e a estratificação social no capitalismo. Disponível em: http://obeco-online.org/roswitha_scholz8. htm. Acesso em: 07/02/2019.

SCHOLZ, R. Gesellschaftliche Form und konkrete Totalität. Zur Dringlichkeit eines dialektischen Realismus heute. EXIT!, 6, 2009a, p. 55-100 [ed. port.: Forma social e totalidade concreta. Na urgência de um realismo dialéctico hoje. Trad. Boaventura Antunes. Disponível em: http://obeco-online.org/roswitha_scholz12. htm. Acesso em: 07/02/2019.

SCHOLZ, R. „Maria breit den Mantel aus. Produktion und Reproduktion in der Krise des Kapitalismus", Phase 2, n. 36, 2009b [ed. port.: Estende o teu manto, Maria! Produção e reprodução na crise do capitalismo. Disponível em: http://www.obeco-online. org/roswitha_scholz13.htm. Acesso em: 07/02/2019].

SCHOLZ, R. Das Geschlecht des Kapitalismus. Feministische Theorien und die postmoderne Metamorphose des Patriarchats, Bad Honnef, $2^{\mathrm{a}}$ ed., 2011 [ed. port. Parcial: O Sexo do Capitalismo. Teorias Feministas e Metamorfose Pós-Moderna do Patriarcado. Disponível em: http://obeco.no.sapo.pt/livro_sexo_capitalismo.htm. Acesso em: 07/02/2019.

SCHOLZ, R. Feminismus - Kapitalismus - Ökonomie - Krise. Wert-Abspaltungstheoretische Einwände gegenüber einigen Ansätzen feministischer Ökonomiekritik heute. Exit!, 11, 2013, p. 15-63 [ed. Port.: Feminismo - capitalismo - economia - crise. Objecções da crítica da dissociação-valor a algumas abordagens da actual crítica feminista da economia. Disponível em: http://obeco-online.org/roswitha_scholz17.htm. Acesso: 07/02/2019.

SCHOLZ, R. „Fetisch Alaaf! Zur Dialektik der Fetischismuskritik im heutigen Prozess des 'Kollaps der Modernisierung'. Oder: Wieviel Establishment kann radikale Gesellschaftskritik ertragen?“. EXIT! Krise und Kritik der Warengesellschaft, 12, 2014, p. 77-117 [ed. port.: Viva o fetiche! Sobre a dialéctica da crítica do fetichismo no actual processo de 'Colapso da modernização'. Ou: quanto establishment pode suportar a crítica social radical? Disponível em: http://www.obeco-online.org/roswitha\%20scholz18. 
htm. Acesso em: 07/02/2019.

WERLHOF, C.; BENNHOLDT-THOMSEN, V.; MARIA, M. "Einleitung" [Introdução]. WERLHOF, C.; BENNHOLDT-THOMSEN, V.; MARIA, M. Frauen, die letzte Kolonie [Mulheres, a última colónia], Reinbeck bei Hamburg, 1983, p. $3-13$. 